\title{
Xylo-Oligosaccharide Utilization by Engineered Saccharomyces cerevisiae to Produce Ethanol
}

\author{
Dielle Pierotti Procópio ${ }^{1}$, Emanuele Kendrick ${ }^{2}$, Rosana Goldbeck ${ }^{3}$, \\ André Ricardo de Lima Damasio ${ }^{4}$, Telma Teixeira Franco ${ }^{5,6}$, David J. Leak ${ }^{2}$, Yong-Su Jin ${ }^{7,8}$ \\ and Thiago Olitta Basso ${ }^{1 *}$ \\ ${ }^{1}$ Department of Chemical Engineering, Escola Politécnica, University of São Paulo, São Paulo, Brazil, ${ }^{2}$ Department of Biology and \\ Biochemistry, Faculty of Sciences, University of Bath, Bath, United Kingdom, ${ }^{3}$ School of Food Engineering, University of \\ Campinas, Campinas, Brazil, ${ }^{4}$ Department of Biochemistry and Tissue Biology, Institute of Biology, University of Campinas, \\ Campinas, Brazil, ${ }^{5}$ Interdisciplinary Center of Energy Planning, University of Campinas, Campinas, Brazil, ${ }^{6}$ School of Chemical \\ Engineering, University of Campinas, Campinas, Brazil, ' DOE Center for Advanced Bioenergy and Bioproducts Innovation, \\ University of Illinois at Urbana-Champaign, Urbana, IL, United States, ${ }^{8}$ Department of Food Science and Nutrition, University of \\ Illinois at Urbana-Champaign, Urbana, IL, United States
}

OPEN ACCESS

Edited by:

Eugene Fletcher,

Escarpment Laboratories Inc.,

Canada

Reviewed by:

Sun-Mi Lee,

Korea Institute of Science and

Technology, South Korea

Rajeev Kumar Sukumaran,

National Institute for Interdisciplinary Science and Technology (CSIR), India

Jeroen Nijland,

University of Groningen, Netherlands

*Correspondence:

Thiago Olitta Basso

thiagobasso@usp.br

Specialty section:

This article was submitted to

Synthetic Biology,

a section of the journal

Frontiers in Bioengineering and

Biotechnology

Received: 30 November 2021

Accepted: 18 January 2022

Published: 15 February 2022

Citation:

Procópio DP, Kendrick E, Goldbeck $R$, Damasio ARdL, Franco TT, Leak DJ,

Jin Y-S and Basso TO (2022) Xylo-

Oligosaccharide Utilization by

Engineered Saccharomyces cerevisiae

to Produce Ethanol.

Front. Bioeng. Biotechnol. 10:825981.

doi: $10.3389 /$ fbioe.2022.825981
The engineering of xylo-oligosaccharide-consuming Saccharomyces cerevisiae strains is a promising approach for more effective utilization of lignocellulosic biomass and the development of economic industrial fermentation processes. Extending the sugar consumption range without catabolite repression by including the metabolism of oligomers instead of only monomers would significantly improve second-generation ethanol production This review focuses on different aspects of the action mechanisms of xylan-degrading enzymes from bacteria and fungi, and their insertion in S. cerevisiae strains to obtain microbial cell factories able of consume these complex sugars and convert them to ethanol. Emphasis is given to different strategies for ethanol production from both extracellular and intracellular xylo-oligosaccharide utilization by $S$. cerevisiae strains. The suitability of $S$. cerevisiae for ethanol production combined with its genetic tractability indicates that it can play an important role in xylan bioconversion through the heterologous expression of xylanases from other microorganisms.

Keywords: Saccharomyces cerevisiae, xylo-oligosaccharides, lignocellulosic ethanol, xylanases, xylose

\section{BACKGROUND}

High fermentative capacity and robustness make Saccharomyces cerevisiae the microorganism of choice for ethanol production. S. cerevisiae strains are the most widely used in the ethanol industry with a well-characterized genome sequence, besides being an efficient expression system for recombinant enzyme production (Hou et al., 2012; Fang et al., 2017; Oh and Jin, 2020). Industrial $S$. cerevisiae strains are highly tolerant against various stresses in industrial environments, such as low $\mathrm{pH}$, high osmotic pressure, high alcohol concentration, and phage contamination. In addition, this yeast presents high ethanol productivity, resulting from the naturally selective process that occurs during the successive fermentations involving pitching between fermentation tanks (Della-Bianca et al., 2014; Nielsen, 2019).

Economic production of second-generation biofuels should include the efficient and simultaneous co-fermentation of all hydrolysable sugars derived from cellulose and hemicellulose ( $\mathrm{Li}$ et al., 2015). Lignocellulose-derived ethanol provides environmental and 
economic benefits, as significant reductions in the disposal of solid wastes, and less air pollution, besides representing a promising industry in the expected transition from fossil to renewable fuels and chemicals. This biofuel is an environmentally friendly liquid fuel because the exhaust carbon dioxide is being taken up by growing plant biomass, contributing to the reduction of $\mathrm{CO}_{2}$ content in the air, which in turn, contributes to the equilibrium of the earth's atmosphere (Palmqvist and Hahn-Hägerdal, 2000a; Jacobsen and Wyman, 2000; Galbe and Zacchi, 2002).

Hemicellulose and cellulose are the major components of the secondary layers of the cell wall in wood fiber, shaping the wellknown natural composition of, lignocellulosic biomass, along with lignin and minor components such as extractives and minerals (Gírio et al., 2010). Lignocellulose represents the most abundant source of renewable material on earth. This material can be found in agricultural residues, forestry waste, municipal solid waste, woods, and grasses, making them widely available at low cost, which is advantageous to the industrial context (Palmqvist and Hahn-Hägerdal, 2000b; Dahlman et al., 2003). Hemicellulose is a heterogeneous group of polysaccharides that comprises 15-35\% of plant biomass (Gírio et al., 2010). Achieving $31.4 \%$ in switchgrass (Sun and Cheng, 2002), 29.3\% in willow (Jorgensen et al., 2007), 28.6\% in sugarcane bagasse (Fernandes Pereira et al., 2011), 22.1\% in corn stover (Jorgensen et al., 2007), 19.7\% in birchwood (Jorgensen et al., 2007) and $18 \%$ in spruce (Tengborg et al., 1998). Besides different amounts, the distribution of hemicellulose varies significantly between different plants. Depending on the source of the biomass (softwoods or hardwoods), its structure and composition can also vary. Softwood hemicellulose (pine and spruce, for example) presents a higher proportion of mannose and glucose units than hardwood hemicellulose (such as Eucalyptus, willow, and oak), which in turn, has a higher ratio of xylose units typically acetylated (Palmqvist and Hahn-Hägerdal, 2000b; Dahlman et al., 2003). The dominant hemicellulose polymer in hardwood biomass, xylan, is composed of repeating $\beta$ (1-4)-linked xylose residue backbone, with acetyl and (methyl)glucuronic acid side groups. However, variations exist in its structures between different species (Rennie and Scheller, 2014; Wierzbicki et al., 2019).

Until recently, xylan represented the main component of plant biomass that cannot be efficiently utilized for biofuels production by fermentation using modified $S$. cerevisiae yeast strain. However, in 2004, Katahira and coauthors first demonstrated that a xylose-consuming $S$. cerevisiae strain expressing xylanolytic enzymes was able to produce ethanol from hemicellulose fraction although in lower levels (Katahira et al., 2004). Xylooligosaccharides (XOS)-consuming S. cerevisiae strains can represent an essential step to reach a more cost-effective second-generation ethanol production, conferring three significant advantages: 1) less intensive pre-treatment conditions would be required - harsh lignocellulosic pretreatment has been applied to release monomers (fermentable sugars), however during this process several yeast growth inhibitors are formed, such as furans, organic acids, phenols, and inorganic salts. Different aspects can interfere with the severity of the pretreatment process, which include holding time, $\mathrm{pH}$, and temperature (Pedersen and Meyer, 2010). The lower severity process can result in high amounts of oligosaccharides, lower monosaccharides, and lower inhibitors compounds, as presented by Brenelli et al. (2020). In their study, the authors evaluated the effect of a mild deacetylation treatment accomplished by hydrothermal pretreatment of raw sugarcane straw and achieve $81.5 \%$ of soluble hemicellulose with XOS yields up to $9.8 \%$ (w/w of an initial straw). These investigators found that an increase in the pretreatment temperature from 180 to $210^{\circ} \mathrm{C}$, achieving a severity factor greater than 4 , was accompanied by an increase in xylose production and lower oligosaccharides production. Under a lower severity factor condition (3.95) the crude hydrolysate yielded approximately $13.5 \mathrm{~g} \mathrm{~L}^{-1}$ soluble XOS as well low amounts of arabinose, xylose, formic acid, acetic acid, and furfural were obtained. Increased temperature is related to an increase in the severity of the treatment, resulting also in the formation of inhibitors for both the enzymatic and fermentation processes (Pedersen and Meyer, 2010). It is worth mentioning that the depolymerization of cellulose and solubilization of hemicellulose and lignin vary according to the proposed pretreatment process and the severity factor applied in the respective process (Lynd et al., 2002). Moreover, the preparation of hemicellulose hydrolysate includes acid addition, high pressure and temperature which cause environmental pollution and equipment corrosion; therefore, successful ethanol production through XOS fermentation would make the process more environmentally friendly (Woodward and Wiseman, 1982; Gueguen et al., 1997; Nevoigt, 2008; Li et al., 2013); 2) lower demand for xylanolytic enzymes would be required, achieving lower production costs-the biomass enzymatic hydrolysis is a crucial step in the overall process due to its relatively large contribution to the total cost of lignocellulosic-derived ethanol (Nieves et al., 1997; Galbe and Zacchi, 2002); to maximize xylose yield and minimize the production of inhibitors, higher amounts of xylanolytic enzymes are required for total degradation of xylan and XOS which is prohibitively expensive on an industrial scale (Galbe and Zacchi, 2002), milder pretreatment methods have been described and 3) industrial competitive advantages (mainly for recombinant microorganism which are able to uptake and consume XOS internally)-it is expected that XOS-consuming $S$. cerevisiae strains would have a competitive advantage concerning other microorganisms, such as contaminating bacteria and wild Saccharomyces and non-Saccharomyces species that naturally use xylan as carbon source (Cabrini and Gallo, 1999; Amorim et al., 2011). It is important to point out that, in order to obtain a second-generation ethanol cost-competitive with first-generation ethanol, it is crucial to obtain microorganisms with unique genotype features to hydrolyze hemicellulose internally through recombinant DNA technology, which represents the best option to overcome the barriers to the commercial exploitation of lignocellulosic bioethanol.

Heterologous expression of xylose and XOS-producing enzymes in $S$. cerevisiae has been extensively reported. However, only one study has reported an $S$. cerevisiae strain able to break xylan down in an intracellular environment (Li et al., 
TABLE 1 | Literature data on engineered, xylo-oxidoreductase and xylose-isomerase -based S. cerevisiae strains.

\begin{tabular}{|c|c|c|c|c|c|c|c|c|}
\hline Strain & $\begin{array}{l}\text { Parental } \\
\text { strain }\end{array}$ & $\begin{array}{c}\text { Relevant } \\
\text { genotype/features }\end{array}$ & $\begin{array}{l}\text { Culture } \\
\text { conditions }\end{array}$ & $\begin{array}{c}\text { Xylose } \\
\text { specific } \\
\text { consumption } \\
\text { rate }\end{array}$ & $\begin{array}{c}\text { Ethanol } \\
\text { production } \\
\text { rate }\end{array}$ & $\begin{array}{c}\text { Ethanol } \\
\text { productivity }\end{array}$ & $\begin{array}{l}\text { Ethanol } \\
\text { yield } \\
\left(g^{-1}\right)\end{array}$ & Reference \\
\hline LVY34.4 & PE-2 (MAT $\alpha)$ & $\begin{array}{l}\text { XI-Orpinomyces sp. } \\
X Y L A, X K S 1, T A L 1, R K I 1, \\
T K L 1, R P E 1, \Delta g r e 3 \\
\text { evolved }\end{array}$ & $\begin{array}{l}\text { Microaerobic batch, YPX, } \\
3 \% \text { xylose, ICW } 0.25 \mathrm{~g} \\
\text { DCW L }\end{array}$ & $\begin{array}{l}1.320(\mathrm{~g} \\
\left.\mathrm{g}^{-1} \mathrm{~h}^{-1}\right)\end{array}$ & $\begin{array}{l}0.620(g \\
\left.g^{-1} h^{-1}\right)\end{array}$ & ND & 0.460 & $\begin{array}{l}\text { Dos Santos } \\
\text { et al. (2016) }\end{array}$ \\
\hline XUSE & $\begin{array}{l}\text { BY4741 (MAT } \alpha \\
\text { his3 leu2 met15 } \\
\text { ura3) }\end{array}$ & $\begin{array}{l}\text { XI-Piromyces sp. XYLA, } \\
\text { XKS1, TAL1, } \Delta \text { gre3, } \\
\text { spho13, evolved }\end{array}$ & $\begin{array}{l}\text { Microaerobic batch, YSC, } \\
2 \% \text { xylose, } O_{600} 10\end{array}$ & ND & ND & ND & 0.400 & $\begin{array}{l}\text { Tran Nguyen } \\
\text { Hoang et al. } \\
\text { (2018) }\end{array}$ \\
\hline IMU078 & $\begin{array}{l}\text { CEN.PK113-5D } \\
\text { (MATa ura3) }\end{array}$ & $\begin{array}{l}\text { XI-Piromyces sp. XYLA, } \\
\text { RPE1, RKI1, TAL1, TKL1, } \\
\text { NQM1, TKL2, XKS1, } \\
\text { Agre3 }\end{array}$ & $\begin{array}{l}\text { Anaerobic batch, Synthetic } \\
\text { medium with L-aspartate } \\
\text { instead of ammonium } \\
\text { sulfate, } 2 \% \text { xylose, ICW } \\
0.02 \mathrm{~g} \mathrm{DCW} \mathrm{L}^{-1}\end{array}$ & ND & ND & ND & 0.406 & $\begin{array}{l}\text { Bracher et al. } \\
\text { (2019) }\end{array}$ \\
\hline SR8N & $\begin{array}{l}\text { D425-2 (MATa } \\
\text { his3 leu2 ura3) }\end{array}$ & $\begin{array}{l}X \mathrm{R} / X \mathrm{DH}-\text { S. stipitis } X Y L 1 \\
X Y L 2 \text { and } X Y L 3 \\
\text { Lactococcus lactis NoXE, } \\
\Delta \text { pho13, } \Delta \text { ald6 }\end{array}$ & $\begin{array}{l}\text { Microaerobic batch, YNB, } \\
4 \% \text { xylose, } \mathrm{OD}_{600} 10\end{array}$ & $N D$ & ND & $\begin{array}{l}1.220(\mathrm{~g} \\
\left.\mathrm{L}^{-1} \mathrm{~h}^{-1}\right)\end{array}$ & 0.391 & $\begin{array}{l}\text { Kim et al. } \\
\text { (2013b), } \\
\text { Zhang et al. } \\
\text { (2017b) }\end{array}$ \\
\hline YRH1490 & PE-2 (MAT $\alpha)$ & $\begin{array}{l}X \mathrm{R} / X \mathrm{XH}-\mathrm{S} \text {. stipitis } X Y L 1 \\
\text { and } X Y L 2, X K S 1\end{array}$ & $\begin{array}{l}\text { Microaerobic batch, YPX, } \\
8 \% \text { xylose, } \mathrm{OD}_{600} 1\end{array}$ & $N D$ & ND & $\begin{array}{l}0.310(\mathrm{~g} \\
\left.\mathrm{L}^{-1} \mathrm{~h}^{-1}\right)\end{array}$ & 0.330 & $\begin{array}{l}\text { Dias Lopes } \\
\text { et al. (2017) }\end{array}$ \\
\hline
\end{tabular}

ICW, initial cell weight.

$O D_{600}=$ Initial $O D_{600}$

$N D$, no data available.

2015). For this reason, although there are engineering efforts to improve direct xylan utilization by this microorganism, some limitations still remain, such as the affinity between XOS and cell membrane transporters, and the understanding of metabolic pathways regulation. This overview examines all strategies reported to date adopted for the re-construction of XOS assimilation in $S$. cerevisiae yeast strains, focusing on those that bioethanol could be bio-converted from hemicellulose fraction.

\section{LATEST TRENDS IN XYLOSE-UTILIZING S. CEREVISIAE}

Although $S$. cerevisiae strains present all genes required for the xylose fermentation, i.e., xylose reductase (XR), xylitol dehydrogenase $(X D H)$, and xylulokinase $(X K S 1)$, only XKS1 has been functionally expressed. XKS1 phosphorylates xylulose into xylulose-5-phosphate which is introduced into the central metabolism through the pentose-phosphate pathway. Previous studies have reported that the wild type of $S$. cerevisiae is capable of naturally assimilating xylulose as a sole carbon source, although at a low rate, under aerobic conditions. However, xylulose is a rare pentose not widely available in nature and probably due to this, the challenge of directing xylulose fermentation by $S$. cerevisiae has received little attention (Jeffries, 1983; Eliasson et al., 2000; Mittelman and Barkai, 2017; Patiño et al., 2019). Furthermore, xylose fermentation by $S$. cerevisiae requires additional interventions in endogenous genes expression and/or kinetic properties (Patiño et al., 2019).

With a focus on second-generation bioproducts, it is not surprising that many studies have attempted to develop laboratory and industrial engineered $S$. cerevisiae strains capable of simultaneous glucose and xylose fermentation by the expression of heterologous xylose consumption genes (Eliasson et al., 2000; Kuyper et al., 2005; Kwak and Jin, 2017; Li et al., 2019). Many studies have shown that different mutations can improve xylose fermentation by yeast. In Table 1 we benchmark five xylose-utilizing strains with superior ethanol yields on xylose metabolism.

In nature, pentose assimilation is widespread across many prokaryotes and eukaryotes, such as Pseudomonas fragi (Weimberg, 1961), Kluyveromyces lactis (Margaritis and Bajpai, 1982), Scheffersomyces stipitis (Toivola et al., 1984), Candida shehatea (Toivola et al., 1984), Pachysolen tannophilus (Smiley and Bolen, 1982; Toivola et al., 1984), Trichoderma sp. (Kulkarni et al., 1999), Aspergillus sp. (Kulkarni et al., 1999), Cryptococcus adeliae (Petrescu et al., 2000), Pseudoalteromonas haloplanktis (Van Petegem et al., 2002), Hansenula polymorpha (Ryabova et al., 2003), Bacillus halodurans (Honda and Kitaoka, 2004), Bacillus subtilis (Collins et al., 2006), Caulobacter crescentus (Stephens et al., 2007), Plectosphaerella cucumerina (Zhang et al., 2007), Haloferax volcanii (Johnsen et al., 2009), Aurebasidium pullulans (Yegin, 2017). To date, three different pathways for xylose assimilation have been identified in these microorganisms and they are differentiated by the involvement of a phosphorylation step (Figure 1). In the first possibility, xylose is isomerized to xylulose and then phosphorylated to form xylulose-5-P. Two metabolic pathways have been identified which involve this strategy: the redox pathway, involving the combined activity of pyridine-nucleotide-dependent xylose reductase (XR) and xylitol dehydrogenase $(\mathrm{XDH})$, and the isomerization pathway involving the redox-cofactor-independent xylose isomerase (XI). The main 


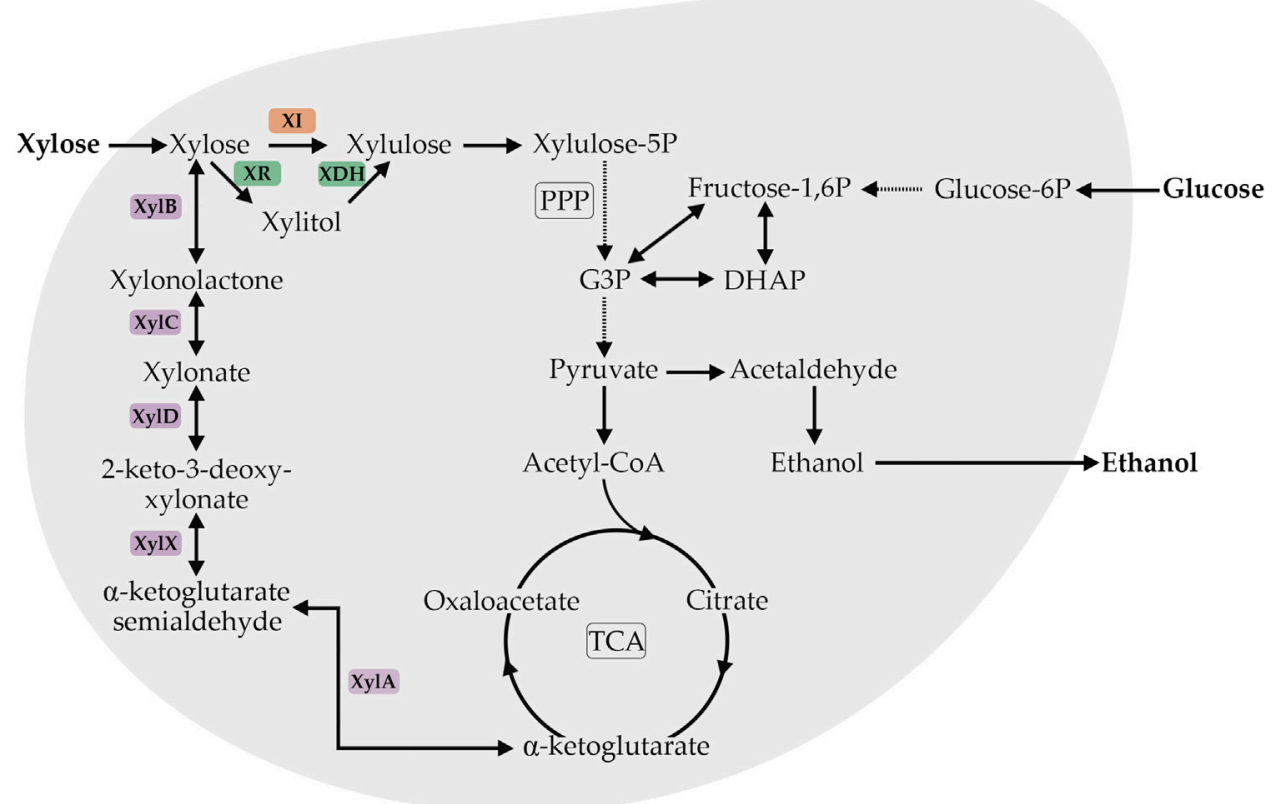

FIGURE 1 | Schematic overview of the xylose degradation pathway associated with the central carbon metabolism in yeast. The orange box indicates the redoxcofactor-independent xylose isomerase (XI), red boxes indicate the pyridine-nucleotide-dependent xylose reductase (XR) and xylitol dehydrogenase (XDH). Purple boxes indicate the five reaction steps of the Weimberg pathway catalyzed by xylose dehydrogenase (XylB), xylonolactonase (XylC), xylonate dehydratase (XyID), 3-keto-2deoxyxylonate dehydratase $(X y \mid X)$, and $\alpha$-ketoglutarate semialdehyde dehydrogenase (XylA). Abbreviations: PPP-pentose phosphate pathway, TCA-tricarboxylic acid cycle, G3P-glyceraldehyde 3-phosphate, DHAP_dihydroxyacetone phosphate. Adapted from Borgström et al. (2019).

difference between these pathways is the dependence on cofactors (oxido-reduction pathway) or not (isomerization pathway). Both metabolic pathways have been used extensively as targets in engineered S. cerevisiae and have been reviewed in detail (Kim et al., 2012, Kim et al., 2013; Harner et al., 2015; Kwak and Jin, 2017; Bracher et al., 2019). The generation of xylulose-5-phosphate via the oxidoreductase pathway allows a link to glycolysis, the central carbon flux, through the non-oxidative part of the pentose phosphate pathway (Stincone et al., 2015). Optimized S. cerevisiae recombinant strains overexpressing XI or XR/XDH have been reported (Table 1). The success of these strategies enables new perspectives on the carbon-source range assimilated by $S$. cerevisiae to be considered. Since xylose assimilation by engineered $S$. cerevisiae strains has become well-established, new approaches have been adopted to enable $S$. cerevisiae to consume XOS instead of xylose and glucose (La Grange et al., 2000, 2001; Fujita et al., 2002; Qian et al., 2003; Katahira et al., 2004; Lee et al., 2009; Sun et al., 2012; Li et al., 2015; dos Reis et al., 2016; Sekar et al., 2016; Zhang et al., 2017a). Scientific interest in this field is increasing steadily, but still much must be done to obtain an efficient XOS-consuming $S$. cerevisiae strain.

An additional xylose assimilation possibility is the so called Weimberg pathway, which is characterized as an oxidative but non-phosphorylating metabolic pathway without xylose to xylulose isomerization. This pathway received much less attention when compared with oxido-reductase and isomerase pathways but recently has gained major attention from research groups (Shen et al., 2020). This pathway provides an alternative entry point for xylose into yeast central metabolism with possibilities to produce new compounds that are intermediates or derivatives from the TCA cycle and provides an interesting route for the production of xylose-derived a-ketoglutarate (Figure 1) (Weimberg, 1961). Recently, the Weimberg pathway enzymes derived from Caulobacter crescentus and Corynebacterium glutamicum were functionally expressed in $S$. cerevisiae; however, pathway intermediates were detected, indicating that this pathway needs further optimization (Borgström et al., 2019). Some of the drawn hypotheses could explain this incompatibility between prokaryotic and eukaryotic proteins, such as deficiency of enzymatic cofactors, posttranslational modifications of the protein, differences in the internal $\mathrm{pH}$ of the parental and the host cell (Sarthy et al., 1987), and the improper folding of the protein (Gárdonyi and Hahn-Hägerdal, 2003; Xia et al., 2016).

\section{XYLANOLYTIC ENZYME SYSTEMS}

The most selective method for the conversion of poly- to monosaccharides is by using enzymes. Most studies on hemicellulases have focused on xylanolytic enzymes, which are responsible for xylan hydrolysis (Gírio et al., 2010). The study of microorganisms able to hydrolyze xylan started more than 130 years ago, probably in 1889 by Hoope-Seyler (Whistler and Masak Jr., 1955). Since then, many organisms with the 


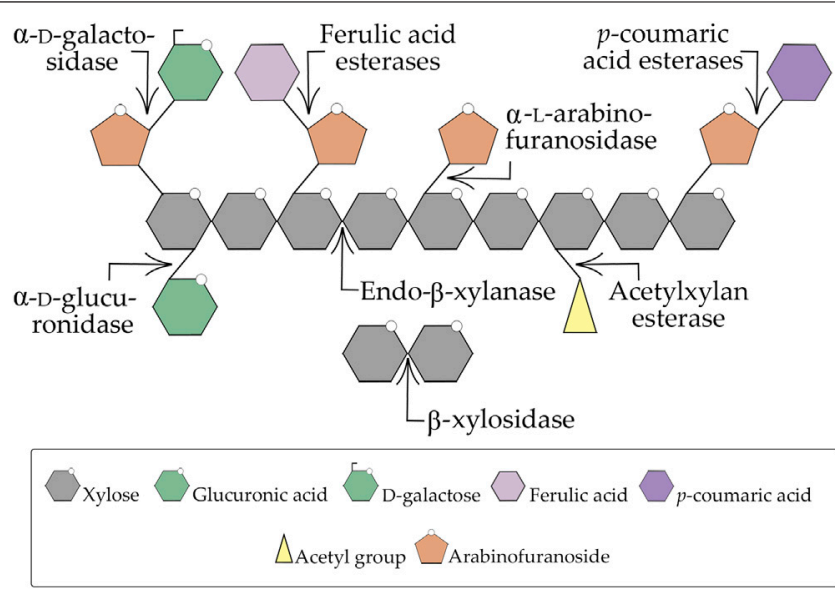

FIGURE 2 | Xylan degradation scheme. The arrows represent each enzyme activity for a determined substrate. Adapted from Bhardwaj et al. (2019).

ability to colonize and grow on plant biomass have been identified. Xylanolytic enzyme producers are widespread, such as fungi, bacteria, yeast, marine algae, protozoans, snails, crustaceans, and insects, of which bacterial and fungal xylanases have the most important role concerning heterologous expression in S. cerevisiae (Jeffries, 1983; Biely, 1985; Kulkarni et al., 1999; Katahira et al., 2004; Schmoll and Schuster, 2010). Trichoderma reesei, Trichoderma atroviride, Trichoderma virens (Beg et al., 2001), Aspergillus niger (La Grange et al., 2001), Neurospora crassa (Li et al., 2015), Aspergillus foetidus (Whistler and Masak Jr., 1955), Bacillus pumilus (Pan et al., 1991) are some examples of potent xylanolytic enzymes producers. These enzymes have potential for the application of xylanases in several industries, such as in the pulp and paper, food additives, animal feed, textiles, drinks industries, ethanol, and xylitol production (Polizeli et al., 2005). The search for newer microbial xylanases producers is ongoing, together with molecular biology studies on the regulation of xylanases expression and their heterologous expression in non-xylanolytic microorganisms.

Xylans represent a family of complex non-cellulosic branched polysaccharides that consists structurally of linear homopolymeric $\beta$-(1,4)-xylopyranosyl units with a diversity of substituted groups, which vary quantitatively and qualitatively according to the plant or the method of isolation. They can be comprised of 4-O-methyl-D-glucuronopyranosyl, $a-\mathrm{L}$ arabinofuranosyl, acetyl, feruloyl and/or $p$-coumaroyl groups (Figure 2) (Wong et al., 1988; Collins et al., 2005; Biely et al., 2016). Wood xylan exists as $O$-acetyl-4-O-methylglucuronoxylan in hardwoods and as arabino-4-O-methylglucuronoxylan in softwoods, which represent the two major forms of xylan in wood, whereas xylans in grasses and annual plants are typically arabinoxylans (Kulkarni et al., 1999). On the other hand, in esparto grass, tobacco stalks, and guar seed husk another type of xylan has been identified, the homoxylans which are composed exclusively of xylosyl residues (Sunna and Antranikian, 1997).

Due to the heterogeneity and complex chemical nature of xylan, its complete breakdown requires the action of a consortium of enzymes with diverse specificities and modes of action (Figure 2). Thus, it is not surprising that xylan-degrading organisms produce a multienzyme system of xylanases that present diverse structures, different mechanisms of action, substrate specificities, hydrolytic activities, and physicochemical characteristics (Beg et al., 2001; Collins et al., 2005; Moreira and Filho, 2016). It is interesting to note that microorganisms can produce multiple forms of the same xylanase family, showing that some factors such as differential processing of mRNA, post-translational modification, proteolytic digestion, and differential expression by distinct alleles of one gene, or even by completely separate genes affect this multiplicity of xylanases secreted (Polizeli et al., 2005; de Vries et al., 2017).

The carbohydrate-active enzymes (CAZy-www.cazy.org) database collectively complies and assigns xylanases are glycoside hydrolases $(\mathrm{GH})$ that catalyze the hydrolysis of 1,4$\beta$-D-xylosidic linkages in xylan. Sequence-based classification has grouped xylanases in two major families GH10 and GH11, but xylanases are also found in other $\mathrm{GH}$ families, 3, 5, 8, 9, 10, 11, 12, 16, 26, 30, 43, 44, 51, 62, 98, and 141 (Collins et al., 2005; Chakdar et al., 2016; Velasco et al., 2019). GH10 members are highly active on short XOS, thereby indicating small substrate-binding sites. The major enzymes of this family are endo- $\beta-1,4$-xylanases (Collins et al., 2005). In contrast, the enzymes that belong to the GH11 family are most active on long-chain XOS. Furthermore, this family is monospecific, which means they are exclusively active on D-xylose-containing substrates (Collins et al., 2005; Chakdar et al., 2016). Some genera of fungi and bacteria produce more than one subfamily of xylanases. However, the majority of the bacterial xylanases belong to the GH10 family, whereas fungal xylanases majorly belong to the GH11 family (Liu et al., 2011).

There is a great diversity of xylanases produced among bacterial genera with Bacillus presenting a potential source of these enzymes (Subramaniyan and Prema, 2002; Gupta and Verma, 2015; Chakdar et al., 2016). Xylanases obtained from bacterial sources are known to be active and stable in a wide range of $\mathrm{pH}$ and temperature, such as temperature from 30 to $60^{\circ} \mathrm{C}, \mathrm{pH}$ 
TABLE 2 | Characteristics of xylanase from different microorganisms functionally expressed in S. cerevisiae.

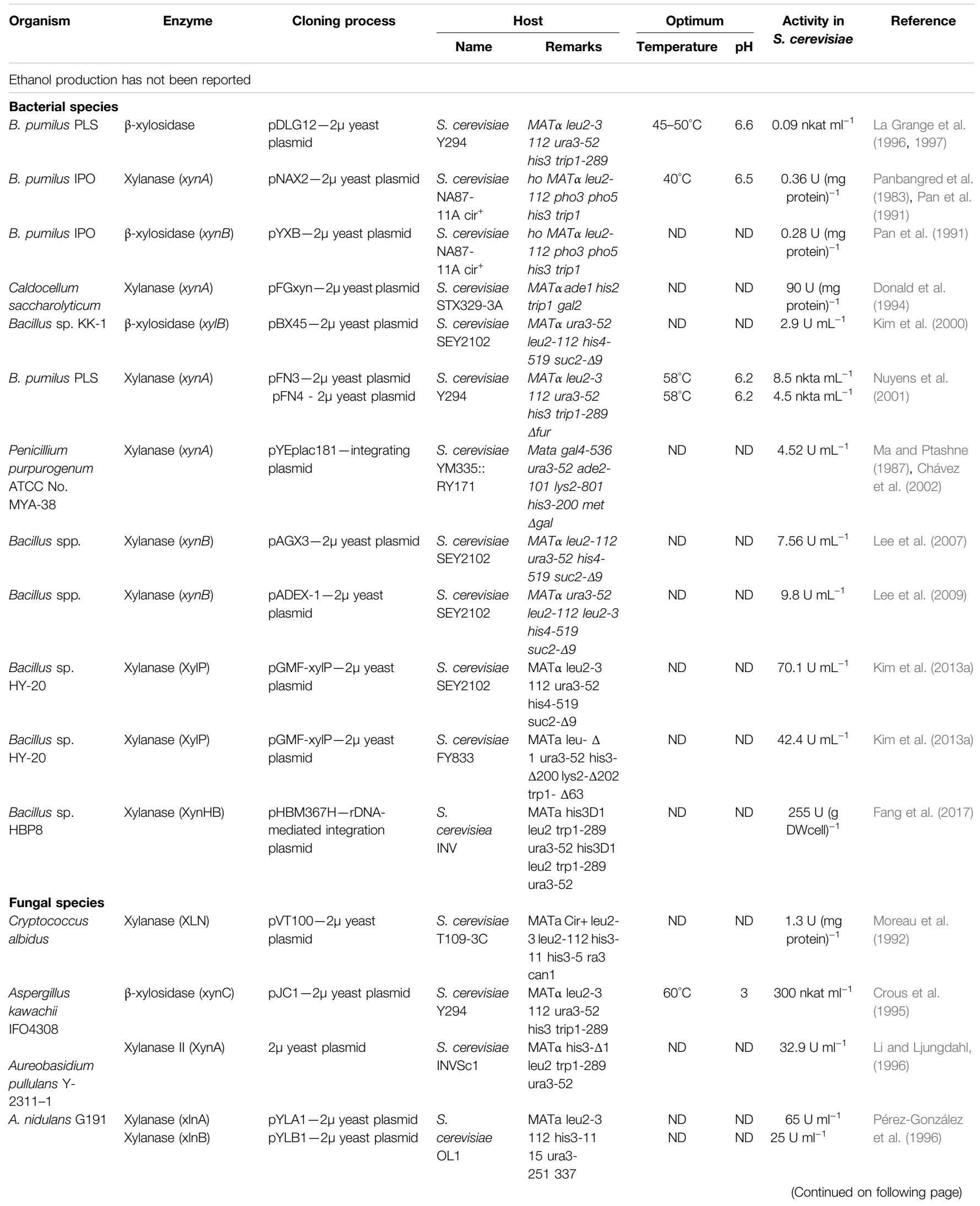


TABLE 2 | (Continued) Characteristics of xylanase from different microorganisms functionally expressed in S. cerevisiae.

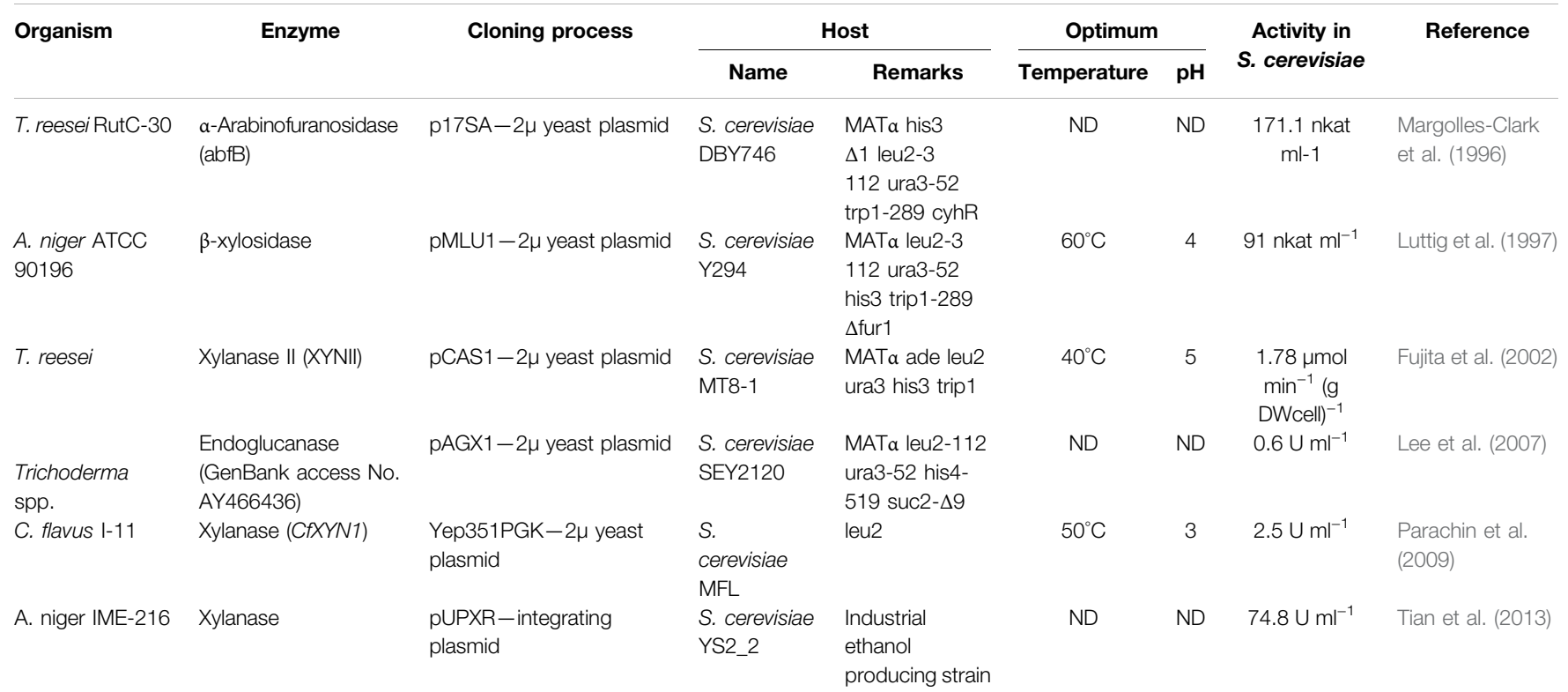

Ethanol production has been reported

Fungal species

A. orizae $\quad \beta$-xylosidase $(\mathrm{Xy} \mid \mathrm{A})$

$\mathrm{NiaD} 300$

$\beta$-xylosidase (XyIA)

pUCSXIIXA-cell-surface

expressing plasmid

S. cerevisiae

MT8-1

MATa ade leu2

his3 ura3 trp1

SsXYL1

SsXYL2

ScXKS1

T. reesei

Xylanase II (XYNII)

QM9414

T. reesei

$\beta$-xylosidase

QM9414

T. reesei

$\beta$-xylosidase (XYL)

pUCSXylAf-integrating

plasmid

pAUR-XSD- $2 \mu$ yeast

plasmid

S. cerevisiae

MA-D4

MATa leu2 his3

ura3 can1

SsXYL1

SsXYL2

ScXKS1 1 aur

S. cerevisiae

OC-2

$\mathrm{MATa} / \mathrm{a}$

SsXYL1

SsXYL2

ScXKS1

T. reesei

$\beta$-xylosidase (XYNII)

p $\delta$ W-GPAGXynll-

integrating plasmid

S. cerevisiae

MT8-1

Mata ade his

leu2 trip1 ura3

SsXYL1

SsXYL2

ScXKS1

$\begin{array}{lll}\text { A. oryzae } & \beta \text {-xylosidase }(X y \mid A) & \begin{array}{l}\text { plHBGXylA-integrating } \\ \text { plasmid }\end{array} \\ \text { T. reesei } & \text { Xylanase II (Xynll) } & \text { pYD1 }-2 \mu \text { yeast plasmid } \\ \text { DSM769 } & & \end{array}$

S. cerevisiae

EBY100

(Invitrogen,

Carlsbad,

CA)

\begin{tabular}{|c|c|c|c|}
\hline A. niger DSM821 & $\beta$-xylosidase $(X \ln D)$ & & \\
\hline A. niger DSM821 & $\begin{array}{l}\alpha \text {-arabinofuranosidase } \\
(A b f B)\end{array}$ & & \\
\hline A. terreus & $\begin{array}{l}\text { Xylanase } \\
\beta \text {-xylosidase }\end{array}$ & pRSK $2-2 \mu$ yeast plasmid & $\begin{array}{l}\text { S. cerevisiae } \\
\text { INVSc1 }\end{array}$ \\
\hline $\begin{array}{l}\text { N. crassa FGSC } \\
2489\end{array}$ & $\begin{array}{l}\beta \text {-xylosidase }(\mathrm{GH} 43-2) \\
\beta \text {-xylosidase }(\mathrm{GH} 43-7)\end{array}$ & pXD8.7 $-2 \mu$ yeast plasmid & $\begin{array}{l}\text { S. cerevisiae } \\
\text { SR8U }\end{array}$ \\
\hline
\end{tabular}

MATa his $3 \Delta 1$

leu2 trp1-289 ura3-52 CtXR

MATa ura3

SsXYL1

SsXYL2

SsXYL3

$\Delta$ pho13 $\Delta$ ald6

$\begin{array}{lll}\text { ND ND } & 234 \cup(\mathrm{g} & \text { Katahira et al. } \\ & \text { DWcell })^{-1} & (2004)\end{array}$

$16 \mathrm{U}(\mathrm{g}$
$\mathrm{DWcell})^{-1}$

ND $\quad$ ND $6 \mathrm{nmol} \mathrm{min}^{-1} \quad$ Fujii et al. (2011) $(\mathrm{mg} \text { protein })^{-1}$

$\begin{array}{cccl}\text { 60 } & \text { ND } & \text { ND } & \begin{array}{l}\text { Saitoh et al. } \\ (2011)\end{array} \\ \text { ND } & \text { ND } & \begin{array}{l}41.2 \cup(g \\ \text { DWcell })^{-1}\end{array} & \begin{array}{l}\text { Sakamoto et al. } \\ (2012)\end{array} \\ & & & \\ & \text { ND } & \begin{array}{c}16.8 \cup(g \\ \text { DWcell) }\end{array} \\ \text { ND } & \text { ND } & \text { Sun et al. (2012) } \\ \text { ND } & \text { ND } & \text { ND }\end{array}$

$\begin{array}{llll}\text { ND } & \text { ND } & \text { ND } & \\ \text { ND } & \text { ND } & \text { ND } & \\ \text { ND } & \text { ND } & \text { ND } & \text { Li et al. (2013) a } \\ & & & \\ \text { ND } & 7 & \text { ND } & \begin{array}{l}\text { Kim et al. (2013b), } \\ \text { Li et al. (2015) }\end{array}\end{array}$

(Continued on following page) 
TABLE 2 | (Continued) Characteristics of xylanase from different microorganisms functionally expressed in S. cerevisiae.

\begin{tabular}{|c|c|c|c|c|c|c|c|c|}
\hline \multirow[t]{2}{*}{ Organism } & \multirow[t]{2}{*}{ Enzyme } & \multirow[t]{2}{*}{ Cloning process } & \multicolumn{2}{|c|}{ Host } & \multicolumn{2}{|l|}{ Optimum } & \multirow{2}{*}{$\begin{array}{c}\text { Activity in } \\
\text { S. cerevisiae }\end{array}$} & \multirow[t]{2}{*}{ Reference } \\
\hline & & & Name & Remarks & Temperature & $\overline{\mathrm{pH}}$ & & \\
\hline \multirow[t]{8}{*}{ U. bevomyces } & Xylanase 1 (XNA1) & P423 $-2 \mu$ yeast plasmid & S. cerevisiae & Mata trp1 can1 & ND & ND & ND & Lee et al. (2015) \\
\hline & Xylosidase 2 (XD2) & $P 424-2 \mu$ yeast plasmid & YSX3 $\Delta$ his & cyn1 gal+ leu2:: & ND & ND & ND & \\
\hline & Arabinofuranosidase & $P 424-2 \mu$ yeast plasmid & & $\begin{array}{l}\text { LEU2-TDH3P- } \\
\text { PSXYL1-TDH3T }\end{array}$ & ND & ND & ND & \\
\hline & & & & Ura3::URA3- & & & & \\
\hline & & & & TDHP-PsXYL2- & & & & \\
\hline & & & & TDH3Т Ту3:: & & & & \\
\hline & & & & G418-PsXYL3 & & & & \\
\hline & & & & $\begin{array}{l}\text { YOR202w:: } \\
\text { hphNT1 }\end{array}$ & & & & \\
\hline \multirow[t]{12}{*}{ T. reesei QM6a } & Endoxylanase (Xyn2) & pVSDis-TrXyn2 - cell- & S. cerevisiae & Mata AGA1:: & ND & ND & $1.197 \cup \mathrm{mg}^{-1}$ & Tabañag et al. \\
\hline & & $\begin{array}{l}\text { surface expressing } \\
\text { plasmid }\end{array}$ & EBY100 & $\begin{array}{l}\text { GAL1-AGA1:: } \\
\text { URA3 ura3-52 }\end{array}$ & & & & (2018) \\
\hline & $\beta$-xylosidase (Bxl1) & pVSDis-TrBxl1 - cell- & & $\operatorname{trp} 1$ leu2- $\Delta 200$ & ND & ND & & \\
\hline & & surface expressing & & his3- $\Delta 200$ & & & & \\
\hline & & plasmid & & pep4::HIS3 & & & & \\
\hline & Acetyl esterase (Axe1) & pVSDis-TrAxe1 - cell- & & prb11.6R can1 & ND & ND & & \\
\hline & & surface expressing & & GAL1 PrXI & & & & \\
\hline & & plasmid & & PrXKS & & & & \\
\hline & a-glucuronidase (GIr1) & pVSDis-TrGlr1 - cell- & & & ND & ND & & \\
\hline & & $\begin{array}{l}\text { surface expressing } \\
\text { plasmid }\end{array}$ & & & & & & \\
\hline & $\alpha$-arabinofuranosidase & pVSDis-TrAbf1 - cell- & & & ND & ND & & \\
\hline & $(A b f 1)$ & $\begin{array}{l}\text { surface expressing } \\
\text { plasmid }\end{array}$ & & & & & & \\
\hline
\end{tabular}

${ }^{a}$ The final goal of this work was xylitol production from xylan. Li et al. (2013) achieved a xylitol yield of $0.71 \mathrm{~g} x y l i t o l\left(g\right.$ xylan) ${ }^{-1}$, and S. cerevisiae recombinant strain, Sc-K2, produced $1.94 \mathrm{~g} \mathrm{~L}^{-1}$ xylitol when cultivated in YPD supplemented with $3 \mathrm{~g} \mathrm{~L}^{-1}$ xylan.

Ss, S. stipitis; Sc, S. cerevisiae; Ct, Candida tropicalis; Pr, Prevotella ruminicola.

$N D$, no data available.

from 5.0 to 9.0 (See some examples in Table 2). These enzymes are produced alone mostly, thereby reducing the downstream process time (Chakdar et al., 2016).

Despite the great diversity of bacterial xylanase producers, filamentous fungi are the major commercial source due to their higher levels of xylanase secretion (Kulkarni et al., 1999; Polizeli et al., 2005). Some works have demonstrated that many fungal species produce xylanase when cultured on cellulose (Mishra et al., 1984; Biely, 1985; Wong et al., 1988), perhaps because the cellulose substrates contain traces of hemicellulose (Polizeli et al., 2005). Nevertheless, in an opposite scenario, several fungal species produce specific xylanases with little or no cellulase background in the presence of xylan, which indicates the xylanolytic and cellulolytic systems are likely to be under separate regulatory control (Biely, 1985; Wong et al., 1988). And interestingly XOS reduced the efficiency of cellulose hydrolysis by cellulase (Zhang et al., 2012; Wang et al., 2018) which cannot be effectively relieved by increasing the loading of the cellulose substrate or cellulase (Wang et al., 2018). However, some fungi species require low $\mathrm{pH}$ for the growth and production of xylanases which necessitates additional steps in the subsequent stages which make fungal xylanases less attractive (Chakdar et al., 2016).

Among xylanases, endo- $\beta$-xylanases (xylanase or endo- $\beta-1,4$ xylanases) and $\beta$-D-xylosidases ( $\beta$-xylosidases or xylosidase) have been most extensively studied. Endo- $\beta$-xylanases (EC 3.2.1.8) randomly cleave the $\beta-1,4$ linkages between the xylopyranosyl units from the xylan backbone, producing mixtures of XOS (Biely, 1985; Kulkarni et al., 1999). $\beta$-D-xylosidases (EC 3.2.1.37) are known to be the major component of xylanase systems. They are produced by biodegradative microorganisms to hydrolyze XOS releasing D-xylose; however, usually, they do not hydrolyze xylan, with their best substrate being xylobiose and their affinity for XOS being inversely proportional to its degree of polymerization. They act on the non-reducing ends of their substrate, XOS and/or xylobiose (Wong et al., 1988; Collins et al., 2005; Polizeli et al., 2005). A high concentration of xylose in the fermentation broth can inhibit the activity of $\beta$ D-xylosidases (Fujii et al., 2011) which leads to the inefficient hydrolysis of hemicellulose and the accumulation of XOS and xylobiose by using microorganisms that do not consume xylose rapidly. Some $\beta$-D-xylosidases have been reported to possess $\alpha-\mathrm{L}$ arabinofuranosidase activity, e.g., the enzymes from A. niger, $T$. reesei, T. ethanolicus, and Penicillium wortmannin (Sunna and Antranikian, 1997). Other enzymes, such as $\alpha-\mathrm{L}$ arabinofuranosidase (EC 3.2.1.55), $\alpha$-D-glucuronidases (EC 3.2.1.139), acetylxylan esterases (EC 3.1.1.72), ferulic acid esterases (EC 3.1.1.73), and p-coumaric acid esterases (EC 3.1.1.-) catalyze the removal of xylan side groups (Collins 
et al., 2005). All these enzymes act cooperatively to convert xylans into xylose, XOS, O-acetyl, L-arabinose, acetic and glucuronic acids (Beg et al., 2001; Polizeli et al., 2005).

Understanding the enzymes xylanolytic microorganisms produce for hemicellulose breakdown may become an important tool for re-construction of their XOS degradation pathway in non-xylanolytic microorganisms. As mentioned before, complete degradation of xylan is achieved by a variety of modular enzymes. Although many hemicellulolytic enzymes have been studied extensively, little is known about how microorganism cells sense the presence of xylan and uptake hemicellulose-derived products (Polizeli et al., 2005; Delmas et al., 2012; Najjarzadeh et al., 2020). The induction signal for the synthesis of xylanolytic enzymes is supposed to involve transporters of xylose and short XOS released by the action of little amounts of the enzymes produced constitutively, along with lactose, glucose, and even cellulose, that are able to cross the membrane and induce the regulatory machinery (Biely and Petráková, 1984; Royer and Nakas, 1989; Chandra Raj and Chandra, 1995; Christakopoulos et al., 1996a, 1996b; Kulkarni et al., 1999), which suggests a complex induction mechanism of xylanases. In their study, Delmas et al. (Delmas et al., 2012) studied the strategy of the filamentous fungus A. niger employ to degrade complex polysaccharides. They showed that wheat straw itself is not initially detected by the A. niger. According to their findings, the overall strategy appears to be an induction of a specific, small scale, sensory response by the onset of carbon starvation, mediated at least partially by alleviation of CreA-dependent catabolite repression, that triggers the release of a small subset of degradative enzymes which initiate degradation on a small scale, in turn releasing sugars that cause the fungus to express its full degradative arsenal (Delmas et al., 2012). More recently, Najjarzadeh and collaborators reported that xylotetraose is more effective than other substrates inducing endoxylanase, while xylohexaose and xylobiose are the best inducers of extracellular $\beta$-xylosidase, and cell-bound $\beta$-xylosidase, respectively (Najjarzadeh et al., 2020).

The driving force for xylose and xylo-oligomers uptake vary considerably among plant cell wall-degrading microorganisms. Several microbial transport systems show to be regulated by two-component systems, responding to environmental or intracellular signals to alter gene expression (Shulami et al., 2007). The two-component system includes two proteins, a receptor histidine kinase, and a response regulator. Each system uses transient phosphorylation of sensory system and a regulatory response of proteins at a specific histidine or aspartate residue for signal, and thus forms a pathway for phosphoryl transfer (Verhamme et al., 2002). Another example of oligomer transport system was described in bacterial species. Some members of the genus Bifidobacterium were found to be able to utilize xylan as a carbon source. A genome sequence analysis of these members have found a variety of genes related to ATP-binding cassette (ABC) sugar transporters (Liu et al., 2014; Chen et al., 2019a; Saito et al., 2020).

\section{HETEROLOGOUS EXPRESSION OF XYLANOLYTIC ENZYMES IN THE YEAST S. CEREVISIAE}

Several reports have described the expression of heterologous endo- $\beta$-xylanases and $\beta$-xylosidase from both prokaryotes and eukaryotes in $S$. cerevisiae to enable the conversion of xylan or XOS into xylose by this species (Table 2). Usually, the complete hydrolysis of xylan requires at least these two enzymes (Biely, 1985): an endo- $\beta$-xylanase that cleaves xylan into XOS with diverse degrees of polymerization, followed by the breakdown of XOS to xylose by $\beta$-xylosidase (Wang et al., 2018). Although endo- $\beta$-xylanases are important for the hydrolysis process, $\beta$ xylosidase is considered a key enzyme (Banerjee et al., 2010), since XOS accumulation can reduce the efficiency of cellulases, such as cellobiohydrolase I (CBHI, from Thermoascus aurantiacus), cellobiohydrolase II (CBHII, from Trichoderma reesei) and endoglucanase II (from $T$. aurantiacus) (Zhang et al., 2012), which would affect conversion yields in simultaneous saccharification and fermentation (SSF) or consolidated bioprocessing (CBP). Therefore, reducing the concentration of XOS using $\beta$-xylosidase represents the best strategy to prevent enzyme inhibition.

The heterogeneous nature of hemicellulose represents a challenge for hemicellulase enzymes. Considering the firstgeneration ethanol industry, a huge amount of lignocellulosebased materials is formed during ethanol production, especially corn stover, sugarcane straw, and sugarcane bagasse, which are particularly attractive as second-generation ethanol feedstock. As mentioned earlier, their hemicellulose content can achieve up to $28 \%$ in sugarcane bagasse (Fernandes Pereira et al., 2011), $27-31 \%$ in sugarcane straw (Almeida and Colombo, 2021), and $22 \%$ in corn stover (Jorgensen et al., 2007). According to the chemical structure of hemicellulose, they present a very similar composition, which includes a high content of acetyl as side groups. Therefore, it is important to highlight that other enzymes would allow more efficient degradation of these hemicellulosic derived materials, such as acetylxylan esterases (EC 3.1.1.72) in combination with xylanase and xylosidase for hydrolyzing pretreated hardwood hemicellulose. The presence of acetyl group degrading enzymes may increase the accessibility of the xylose chain to xylanases.

\section{S. CEREVISIAE AS A PLATFORM TO PRODUCE XYLANOLYTIC ENZYMES}

To the best of our knowledge, the first report of xylandegrading genes expression in S. cerevisiae was in 1991, when Pan et al. (1991) described the expression of two enzymes, xylanase (a $x y n A$ gene product) and $\beta$-xylosidase (a $x y n B$ gene product) from Bacillus pumilus in yeast cells. Thereafter, physiological data related to the expression of the intracellular $\beta$-xylosidase from B. pumilus in S. cerevisiae has been published (Crous et al., 1995; Crous et al., 1996; La Grange et al., 1996; La Grange et al., 2000). A successful expression of a bacterial $\beta$-xylosidase from B. pumilus (xynB) 
in yeast cells was achieved by its fusion to a native secretion signal sequence named mating pheromone $\alpha$-factor (MFa1s) (La Grange et al., 1997). The native open-reading frame of these enzymes starts with the codon TTG which is not recognized by $S$. cerevisiae for the initiation of translation. Even after replacing the TTG codon with an ATG starting codon, no $\beta$-xylosidase activity could be detected by the recombinant S. cerevisiae Y294 (La Grange et al., 1997).

Although there has been some success in functional expression of bacterial enzymes in S. cerevisiae (Table 2), this can be problematic, possibly because of incompatibility with eukaryotic chaperones (Sarthy et al., 1987; Gárdonyi and Hahn-Hägerdal, 2003; Xia et al., 2016). The heterologous expression of eukaryotic xylanases in $S$. cerevisiae naturally shows more compatibility since fungal species share many features, particularly related to transcription, translation, and protein stability (Frommer and Ninnemann, 1995). The first recombinant S. cerevisiae strain (namely IAF130) expressing heterologous eukaryotic xylanase was described by Moreau et al. (1992). However, because the cells could not catabolize xylose, the majority of the early reports of recombinant $S$. cerevisiae expressing $\beta$-xylosidases only demonstrated the conversion of xylan and XOS into xylose, xylobiose, and xylotriose, but not to ethanol.

Heterologous expression of the $T$. reesei xylanase II (XYNII) anchored on the cellular surface was described in the $S$. cerevisiae strain MT8 by using a cell surface engineering system based on $a$-agglutinin which consist of the fusion of the protein with the C-terminal-half region of an agglutinin. The recombinant strain MT8-1/pCAS1-XYNII was able to hydrolyze birchwood xylan into xylobiose and xylotriose. The proposed work did not aim to present a hydrolytic profile during the growth of MT8-1/pCAS1-XYNII in a medium containing complex sugar. Instead, xylanase activity was measured in both supernatant and pellet fractions from pre-cultured strain. XYNII activity was detected in the cell pellet with no leakage into the supernatant medium (Fujita et al., 2002).

\section{ETHANOL PRODUCTION FROM XOS BY EXTRACELLULAR EXPRESSION OF XYLANOLYTIC ENZYMES IN S. CEREVISIAE STRAINS}

The first example of the concept of CBP applied to ethanol production from xylan using recombinant $S$. cerevisiae strain without the addition of exogenous xylan-degrading enzymes was described in 2004 (Katahira et al., 2004). In their work, xylanase II (XYNII) from T. reesei QM9414 and $\beta$-xylosidase (XylA) from Aspergillus oryzae NiaD300, were co-displayed on the cell surface of xylose-consuming $S$. cerevisiae harboring genes encoding the oxidoreductase pathway from $S$. stipitis and native xylulokinase (XKS) from S. cerevisiae. To obtain this strain, the C-terminal region of $\alpha$-agglutinin was fused to both xylanolytic enzymes. The constitutive expression of XYNII and Xyla enabled xylan consumption and ethanol production without a lag-phase. The recombinant strain MT8-1/pUCSXIIXA/pWX1X2XK produced $7.1 \mathrm{~g} \mathrm{~L}^{-1}$ of ethanol after $62 \mathrm{~h}$ of fermentation in semi defined medium supplemented with birchwood xylan corresponding to $100 \mathrm{~g}$ of total sugar per liter as the sole carbon source. Despite the significant ethanol production, a large amount of xylan remained in the growth medium, suggesting that this strain needs further optimization.

Microbial surface display technology allows the expression of peptides and proteins on the surface of living cells in which proteins are expressed extracellularly, however, the enzymes remain fused at the cell with no leakage into the culture medium (Fujita et al., 2002; Katahira et al., 2004; Tafakori et al., 2012). Other examples of coexpression of xylanolytic enzymes anchored on the $S$. cerevisiae cellular surface considered the expression of bifunctional minihemicellulosomes, with several assembled modules included (Sun et al., 2012). Sun and coauthors constructed a recombinant yeast that directly produced ethanol from birchwood xylan through the expression of bifunctional minihemicellulosomes. This recombinant strain co-displays two complementary xylanases, XYNII and an $A$. niger xylosidase $(X D N L)$ as well as a mini scaffolding (CipA3), which served as the basis to establish interaction between the enzymes and cell surface. According to their findings, the HZ3345 strain was able to ferment xylan into ethanol. The recombinant $S$. cerevisiae strain also contained an integrated xylose-utilizing pathway (XR, $\mathrm{XDH}$, and $\mathrm{XK}$ from $S$. stipitis) to ensure the xylose assimilation. Interestingly, xylose production was immediately observed from XOS, without any lag phase, as previously observed (Katahira et al., 2004). The recombinant HZ3345 strain, produced $0.95 \mathrm{~g} \mathrm{~L}^{-1}$ of ethanol from approximately $3.0 \mathrm{~g} \mathrm{~L}^{-1}$ birchwood xylan after $80 \mathrm{~h}$ of cultivation under anaerobic conditions in YPBX (YP supplemented with birchwood xylan) supplemented with Tween and ergosterol.

In a more recent study, a blended bioprospecting approach was applied (Lee et al., 2015) along with rational and evolutionary engineering to improve xylan assimilation in an engineered xylan-catabolizing $S$. cerevisiae strain. The extracellular expression of xylan active enzymes (xylanase 1-XNA1, xylosidase 2-XD2, and arabinofuranosidase-AFB) from Ustilago bevomyces were cloned into $2-\mu \mathrm{m}$ plasmids, p423 and p424 under the control of the GPD promoter. These plasmids were transformed into the $S$. cerevisiae YSX3 $\Delta$ his 3 strain, which has the xylose consumption pathway genes from $S$. stipitis integrated. Before applying the evolutionary approach, the recombinant strains grew slowly on xylan as a sole carbon source, producing $0.26 \pm 0.008 \mathrm{~g} \mathrm{~L}^{-1}$ ethanol from YPXN (YP supplemented with $20 \mathrm{~g} \mathrm{~L}^{-1}$ xylan) after 5 days of cultivation. To improve its ability to assimilate xylan, serial-subcultures in the xylan medium were used over 3 weeks. After selecting clones with improved traits, the evolved strain was able to produce $23 \%$ more ethanol in complex media (YPXN, 2\% xylan), $0.32 \pm 0.028 \mathrm{~g} \mathrm{~L}^{-1}$. These results demonstrate the capacity to use whole-cell adaptive evolution to improve xylan metabolism by the cell. 
The often-emphasized advantage of the xylose isomerase pathway in comparison with the oxidoreductase pathway was considered by Mert et al. (2016). In the earlier studies (Katahira et al., 2004; Fujii et al., 2011; Sun et al., 2012), engineered S. cerevisiae strains with $\mathrm{XR} / \mathrm{XDH}$ were modified by the introduction of xylanolytic enzymes. Although the authors observed ethanol production from XOS, large amounts of xylose remained in the fermentation broth, probably resulting from a redox imbalance and/or inefficient xylose uptake; this, in turn, can inhibit $\beta$-xylosidase activity (Fujii et al., 2011; Peng et al., 2017; Niu et al., 2019). However, early attempts to express xylanases in engineered $S$. cerevisiae strains harboring XI had failed to produce ethanol from beechwood xylan (5\%) as the sole carbohydrate source under aerobic growth over 28 days (Mert et al., 2016). The recombinant strain, Y294 [YMXI], which carries T. reesei endoxylanase $(X Y N I I), A$. niger $\beta$-xylosidase $(x \ln D), S$. stipitis xylulokinase ( $x y l 3)$, and the codon-optimized xylose isomerase encoding gene ( $x y l A)$ from Bacteroides thetaiotaomicron was able to break down xylan into trisaccharide, disaccharides, and monosaccharides. However, the growth rate was low probably due to the low consumption of xylose. The small amounts of xylose consumed supported cell biomass synthesis only; ethanol, xylitol, glycerol, and acetic acid production were negligible. It is worth noting that when this recombinant strain Y294 [YMXI] was cultivated under similar conditions but using xylose (2\%) as the sole carbon source, higher biomass was obtained, and larger amounts of xylose were consumed in a lower cultivation time. Moreover, xylitol production was also observed (Mert et al., 2016). Unfortunately, whether the expressed xylanolytic enzymes were secreted or expressed intracellularly in the Y294 [YMXI] strain is not clear. It is important to mention that in previous studies published by this research group, using a $S$. cerevisiae expressing an endoxylanase encoding gene (xyn2) and a xylosidase encoding gene $(x \ln D)$, enzyme activities were detected in the culture supernatant (La Grange et al., 2001), suggesting that these enzymes were secreted by the strain.

Recombinant gene expression can promote a nonspecific metabolic burden which reduces the maximum specific growth rate and production yield of the host, as previously observed (Görgens et al., 2001). In this research, T. reesei xylanase II (XYN2) was expressed in two recombinant $S$. cerevisiae strains, Y294 [PGK1-XYN] and Y294 [ADH2-XYN], using two 2- $\mu \mathrm{m}$ yeast plasmids under the control of either the yeast glycolytic phosphoglycerate kinase (PGK1) or alcohol dehydrogenase II $(A D H 2)$ promoters, respectively. $A D H 2$ is a strong promoter inducible in the absence or at low concentrations of glucose, while $P G K 1$ is a constitutive promoter. However, no significant difference was observed for XYN2 expression by Y294 [ADH2-XYN] and Y294 [PGK1-XYN] strains. After $80 \mathrm{~h}$ of cultivation in a defined medium (Verduyn et al., 1992) containing $20 \mathrm{~g} \mathrm{~L}^{-1}$ glucose, specific xylanase production levels were 3.2 and $2.6 \mathrm{mg}$ (g biomass) ${ }^{-1}$, respectively. The fermentation parameters of Y294 [PGK1-XYN] and Y294 [ADH2-XYN] were compared with those of the reference strains. In all Y294 [PGK1$\mathrm{XYN}$ ] and Y294 [ADH2-XYN] cultivations, a reduction in yeast biomass, ethanol, and glycerol yields were observed as well as specific consumption and production rates of glucose and ethanol, compared with the reference strains. Therefore, the expression of XYN2 from either PGK1 or $A D H 2$ promoters resulted in a significant metabolic burden on the host metabolism.

These findings might explain the results obtained by Mert et al. (2016), who found lower biomass production in the engineered strain Y294 [YMXI] during cultivation on xylan than in xylose as sole carbohydrate source. It is likely that the metabolic burden associated with the expression of xylanolytic enzymes impacted xylose isomerase activity. Unfortunately, xylanase activity assays during cultivation on xylan were not reported (Mert et al., 2016). The influence of $A D H 2$ and $P G K 1$ on xylanase expression was also examined by (Nuyens et al., 2001). They also used two $2-\mu \mathrm{m}$ yeast plasmids named pFN3 and pFN4 to insert endoxylanase (xynA) of B. pumilus PLS into S. cerevisiae Y294 strain under the control of these two different promoters. The two engineered yeast strains did not exhibit any xylanase activities until the gene encoding uracil phosphoribosyl transferase (FUR1) was disrupted. This step ensured auto-selection of the URA3bearing expression plasmid in a rich growth medium since mutants by FUR1 disruption allow the growth of the recombinant yeasts in a complex medium without the risk of losing the plasmid (La Grange et al., 1996). However, unlike the work of (Görgens et al., 2001), Y291 [pFN3 fur1:LEU2], in which the xylanase was under the control of the $A D H 2$ promoter, exhibited better xylanase activity (and presumably, expression) in the culture supernatant than Y291 [pFN4 fur1::LEU2], specifically $8.5 \mathrm{nkat} \mathrm{ml}^{-1}$ and $4.5 \mathrm{nkat} \mathrm{ml}^{-1}$, respectively.

Recently Niu et al. (2019), reported ethanol production from an efficient xylose-utilizing strain, BSPX042, expressing a xylose isomerase gene derived from a bovine rumen metagenomic study (Ru-xylA), cloned in an episomal plasmid (pJXIH-PC, URA3 as a select marker) carrying the $\beta$-xylosidase from Penicillium oxalicum $(x y l 3 A)$ and the signal peptide fragment INU from Kluyveromyces sp. The recombinant strain, BSGIBX, cultivated in a selective synthetic complete medium supplemented with $20 \mathrm{~g} \mathrm{~L}^{-1}$ XOS, immediately converted XOS into xylobiose and xylotriose after inoculation. The highest ethanol concentration, approximately $4,37 \mathrm{~g} \mathrm{~L}^{-1}$, was reached at $36 \mathrm{~h}$. When the XOS were pretreated with xylanase, the ethanol concentration reached approximately $9 \mathrm{~g} \mathrm{~L}^{-1}$. Another important study involving the use of the XI pathway and xylanases is the work of (Tabañag et al., 2018). They expressed five different hemicellulases: endoxylanase (XYNII), $\beta$-xylosidase (Bxl1), acetylxylan esterase (Axe1), $\alpha$-Dglucuronidase $(G l r 1)$ and $\alpha$-L-arabinofuranosidase $(A b f 1)$, all from $T$. reesei, bound to the cell surface of a XI-expressing $S$. cerevisiae strain. Since hemicellulose is a complex structure that requires a consortium of enzymes to break it down completely, the authors explored accessory enzymes to make the main-chain more accessible to main-chain cleaving hemicellulases. The recombinant strain grew on xylan substrates as their sole carbon source and achieved an ethanol titer of $0.96 \mathrm{~g} \mathrm{~L}^{-1}$ after $160 \mathrm{~h}$ of cultivation.

In the context of a lignocellulosic biorefinery, in order to make full use of cellulose and hemicellulose to produce ethanol, Lee et al. (2007) investigated constitutive co-expression of 
endoxylanase (xynA) from Bacillus spp. and endoglucanase (egl6) from Trichoderma spp. in S. cerevisiae SEY2102 strain. The expression levels of endoxylanase and endoglucanase were investigated during aerobic cultivation on YPD medium. Although fermentative parameters were not investigated, $5.6 \mathrm{U} \mathrm{mL}^{-1}$ of endoxylanase was secreted into the extracellular medium, and $1.96 \mathrm{U} \mathrm{mL}^{-1}$ was intracellular after $48 \mathrm{~h}$ cultivation. However, these findings are still far from achieving the goal of ethanol bioconversion from cellulosic biomass. The most promising strategy for converting cellulosic biomass to ethanol in yeast is certainly the concerted heterologous expression of all main types of hemicellulases and cellulases enzymes to maximize their synergies and improve ethanol production (Nevoigt, 2008).

Similarly to the previous report, Saitoh et al. (2011) have reported the expression of $\beta$-xylosidase and $\beta$-glucosidase from $T$. reesei on the yeast cell surface based on $\alpha$-agglutinin engineering system, obtaining the engineered industrial $S$. cerevisiae strain OC2-AXYL2-ABGL2-Xyl2 which also contains the oxidoreductase pathway for xylose consumption. The highest ethanol concentration, $12.5 \mathrm{~g} \mathrm{~L}^{-1}$, was observed after $48 \mathrm{~h}$ in YPKX medium $\left(40 \mathrm{~g} \mathrm{~L}^{-1} \mathrm{KC}\right.$-flock and $40 \mathrm{gL}^{-1}$ xylan from Birchwood) containing $30 \mathrm{~g} \mathrm{~L}^{-1}$ cellulose. The ethanol yield was $0.52 \mathrm{~g}$ (g sugar consumed $)^{-1}$. Another example of the coexpression in $S$. cerevisiae of cellulase and hemicellulose enzymes, including an endoxylanase, xylosidase, and glucosidase was reported by (Sakamoto et al., 2012). These authors expressed endoxylanase from T. reesei, $\beta$-xylosidase from Aspergillus oryzae, and $\beta$-glucosidase from A. aculeatus anchored on the surface cell of the laboratory xylose-assimilating S. cerevisiae MN8140/XBX. Therefore, the recombinant strain, MN81/XBXX, expressed XR and XDH from S. stipitis, xylulokinase from $S$. cerevisiae, in addition to xylanases, and cellulase enzymes. The strain was reported to ferment cellulose and hemicellulose giving a high ethanol yield, $0.32 \mathrm{gg}^{-1}$, and concentration of $8.2 \mathrm{~g} \mathrm{~L}^{-1}$ after $72 \mathrm{~h}$, from rice straw under oxygen-limited conditions and initial cell concentration of $100 \mathrm{~g}$ of wet cells $\mathrm{L}^{-1}$. When $0.2 \mathrm{~g} \mathrm{~L}^{-1}$ of a commercial hemicellulase was added at the medium, the recombinant strain reached $10.3 \mathrm{~g} \mathrm{~L}^{-1}$ ethanol after $72 \mathrm{~h}$, and the ethanol yield was $0.41 \mathrm{gg}^{-1}$. The addition of the commercial hemicellulase allows complete hydrolysis of xylobiose after $72 \mathrm{~h}$ of fermentation, which in turn increased xylose content in the medium. Although the depletion of all xylobiose, after $72 \mathrm{~h}$ of fermentation $2.2 \mathrm{~g} \mathrm{~L}^{-1}$ xylose remained in the fermentation medium (Sakamoto et al., 2012).

Lastly, Xiao et al. (2019) also reported the co-expression of both cellulase and xylanase enzymes in $S$. cerevisiae (unfortunately, the authors did not specify what cellulase or xylanase was used in their work). As reported herein, there is a synergistic action between cellulase and xylanase during lignocellulosic hydrolysate (Zhang et al., 2012; Wang et al., 2018; Xiao et al., 2019). In the presence of such synergies, pretreated lignocellulosic substrate degradation is more efficient because, since XOS can inhibit cellulase activity, the co-expression strategy would reduce the cellulase activity inhibitors (Zhang et al., 2012; Wang et al., 2018). Inside the concept of synergistic effect, it is worth noting that $\beta$-glucosidase did not affect xylanase activity as demonstrated by Chen et al. (2019b). The recombinant strains of Xiao et al. (2019), INVSc1$\mathrm{CBH}-\mathrm{CA}$ and INVSc1-CBH-TS, were cultivated using partly delignified corn stover (PDCS) producing $1.66 \mathrm{~g} \mathrm{~L}^{-1}$ and $1.90 \mathrm{~g} \mathrm{~L}^{-1}$ of ethanol after $120 \mathrm{~h}$ cultivation, respectively. This was approximately 4 times higher than the control (a strain that expressed a single cellulase or xylanase). Although the ethanol production did not exceed that of other published works (Katahira et al., 2004; Fujii et al., 2011; Niu et al., 2019) the effective synergistic effect of those enzymes could improve the saccharification of lignocellulose and increase the ethanol yield during fermentation by S. cerevisiae.

It is important to note that most of the investigations using engineered xylan-consuming $S$. cerevisiae cells have been carried out using laboratory strains, except by the work of (Saitoh et al., 2011). However, based on the industrial conditions for ethanol production, i.e., lignocellulosic inhibitors (Almeida et al., 2007), high osmolarity, and low $\mathrm{pH}$, industrial host backgrounds would present more advantages as compared to laboratory strains (Della-Bianca and Gombert, 2013; Cola et al., 2020).

\section{ETHANOL PRODUCTION FROM INTRACELLULAR XOS UTILIZATION IN S. CEREVISIAE STRAINS}

Economic bioethanol production from lignocellulose requires complete and rapid conversion of both cellulose and hemicellulose on an industrial scale (Li et al., 2015; Mert et al., 2016). This generally includes the pretreatment of lignocellulosic biomass to increase enzyme accessibility, which improves the amount of fermentable sugars from the enzymatic digestion for biomass-to-bioethanol microbial conversion, (Palmqvist and Hahn-Hägerdal, 2000a; Katahira et al., 2004; Lynd et al., 2008). Ultimately, engineered S. cerevisiae expressing XOStransporters and producing active xylanolytic enzymes for the intracellular depolymerization of XOS to xylose are important for reducing the xylanases inhibition by its end products and for tackling the issues of microbial contamination in industrial conditions, as well as for taking full advantage of all of the sugars in lignocellulosic hydrolysate (Fujii et al., 2011; Niu et al., 2019). There is a large amount of data on the expression of xylanolytic enzymes in S. cerevisiae strains, however, few of them report the expression of intracellular XOS hydrolysis system in this yeast (Li et al., 2015). Besides the reduction of xylanases inhibition by its end products, XOS internalization represents an additional advantage over extracellular hydrolysis. The engineered S. cerevisiae would grow faster than other contaminant microorganisms in the fermentation tank.

Neither XOS transporters in S. cerevisiae nor expression of heterologous XOS-transporters expression have been reported in the works mentioned above. Li et al. (2015) reported the first engineered $S$. cerevisiae strain able to consume XOS intracellularly following uptake by an oligosaccharidetransporter. The recombinant strain expressed two $\beta$ xylosidases, GH43-2, and GH23-7, and one transporter, CDT-2, 
from Neurospora crassa as well as $\mathrm{XR} / \mathrm{XDH}$ from $S$. stipitis to ensure the internal breakdown of XOS into ethanol (SR8U) (Kim et al., 2013b; Li et al., 2015). The expression of both $\beta$ xylosidases was essential for converting XOS into xylose as the $\mathrm{XR}$ acted as an XOS reductase, producing xylosyl-xylitol as a potential dead-end product. Although GH43-7 had weak $\beta$ xylosidase activity, it rapidly hydrolyzed xylosyl-xylitol into xylose and xylitol. Anaerobic fermentation with this strain, expressing CDT-2, GH43-2, and GH43-7 in an optimized minimum medium (oMM) containing $4 \%$ xylose and $3 \%$ XOS, produced more than $30 \mathrm{~g} \mathrm{~L}^{-1}$ of ethanol in $72 \mathrm{~h}$ of cultivation, after supplying an additional $50 \mathrm{~g} \mathrm{~L}^{-1}$ xylose at hour 48 (Li et al., 2015). The authors also performed a cofermentation of sucrose plus XOS with the strain SR8U carrying the plasmid pXD8.7. According to their report, the recombinant strain could increase $3 \mathrm{~g} \mathrm{~L}^{-1}$ of ethanol concentration comparing cultivations performed in oMM media containing approximately $60 \mathrm{~g} \mathrm{~L}^{-1}$ sucrose (control cultivation) and the media containing approximately $60 \mathrm{~g} \mathrm{~L}^{-1}$ sucrose and $10 \mathrm{~g} \mathrm{~L}^{-1}$ XOS of which $4.2 \mathrm{~g} \mathrm{~L}^{-1}$ represent xylobiose and $2.3 \mathrm{~g} \mathrm{~L}^{-1}$ xylotriose (Li et al., 2015).

Although Fujii et al. (2011) did not have express a specific XOS transporter, their recombinant strain could hydrolyze xylobiose and xylotriose to xylose intracellularly. They have reported an XOS-fermenting yeast strain, D-XSD/ XKXDHXR, that was constructed by expression of intracellular $T$. reesei $\beta$-xylosidase in a xylose-utilizing $S$. cerevisiae D452-2 strain expressing oxidoreductase pathway from $S$. stipitis. The recombinant strain D-XSD/XKXDHXR produced $4.2 \mathrm{~g} \mathrm{~L}^{-1}$ of ethanol from $10.8 \mathrm{~g} \mathrm{~L}^{-1}$ of xylobiose and $4.1 \mathrm{~g} \mathrm{~L}^{-1}$ of xylotriose after $168 \mathrm{~h}$ of fermentation in SCX medium under anaerobic conditions. The group reported xylose accumulation in the fermentative broth, suggesting that xylose uptake was a rate-limiting step, leading to a long XOS fermentation time. The authors claimed that the extracellular xylose accumulation implies that the cell exported the excess of intracellular xylose since no extracellular $\beta$-xylosidase activity was detected and the XOS hydrolysis occurred in the intracellular environment. These data suggest xylobiose and xylotriose were transported inside the cell using native transporters of the related $S$. cerevisiae strain, probably by saccharide transporters.

As evident from Table 2, chromosomal integrative approaches have not been widely applied to construct the XOS-utilizing $S$. cerevisiae strain. Although laborious, this approach represents the only feasible strategy for engineering genetically stable yeast strains without a select marker, for industrial applications (Nevoigt, 2008; Fang et al., 2017). Fang et al. (2017) reported a promising approach to obtain yeast with a chromosomal multicopy expression of a Bacillus sp. xylanase $(x y n H B)$ in $S$. cerevisiae strain A13. rDNA-mediated integration was used in their work, providing stable expression over 1,011 generations of cultivation, and higher copy numbers of the target gene in the chromosome than from integrating plasmids, i.e., 13.64 copies of $x y n H B$ gene were found in the A13 genome. Yeast genome contains around 100 rDNA repetitive units which provide ideal homologous recombination sites for the target gene. It is worth noting that gene stability is only observed when the integrated plasmid is smaller than the size of the rDNA unit $(9.1 \mathrm{~kb})$ (Lopes et al., 1996). The A13 strain lacked the enzymes required to form xylulose from xylose, therefore ethanol production was not the goal of Fang's research.

\section{CONCLUDING REMARKS AND PROSPECTS}

Although xylan-degrading enzyme systems have been studied extensively, there are much more missing points to connect than cellulose-degrading enzyme systems, probably because the structure of xylan is more complex and varies from plant to plant. However, the xylanolytic enzyme system deserves the same attention as the cellulolytic systems because their biotechnological potential is equally important. S. cerevisiae wild type strains are not suitable for producing bioethanol, even from a lignocellulosic hydrolysate with minimized production of inhibitors and high concentrations of hemicellulose/cellulose-derived oligosaccharides. A xylo-oligosaccharide-assimilating pathway has been demonstrated to be effective to generate $S$. cerevisiae strains able to convert polysaccharides into monomers. The effective intracellular hydrolysis of XOS has been demonstrated, however, the development of a strain capable of transporting large molecules of XOS is a crucial challenge. Screening for non-glucose specific transporters, such as xylose and xylo-oligomers specific transporters, and intracellular endoxylanases might advance strain improvement for efficient biomass conversion.

Significant improvements towards ethanol production from hemicellulose have been achieved in recent years, as the synergistic effect of overexpressing a combination of $\beta$ xylosidases, xylanases, and cellulases have been established (La Grange et al., 2000; Chen et al., 2019b; Xiao et al., 2019); however, there are potential limitations for efficient ethanol production from xylan by engineered $S$. cerevisiae, for example, $\beta$-Xylosidases with lower inhibition by products are needed for future $S$. cerevisiae engineering in order to achieve the complete conversion of xylobiose or xylotriose into xylose (Niu et al., 2019). In addition, it needs to be recognized that xylan in hemicellulose is typically branched and decorated, requiring accessory enzymes for their removal. Nevertheless, improvements in the technology to engineer and evolve $S$. cerevisiae, together with our current state of knowledge suggest that there is a high potential for the application of xylanolytic enzymes to obtain mono- and oligosaccharides from pretreated lignocellulose followed by fermentation into ethanol, since the cost of such sugars has historically been far too high to attract industrial interest.

Concerning the actual large-scale bioethanol production process from sugar- and starch-containing feedstock, hemicellulosic-derived bioethanol is still in its infancy due to low ethanol yield achieved by the abovementioned engineered $S$. cerevisiae strains. However, it is worth mentioning that lignocellulosic hydrolysate contains a mix of carbon sources, such as cello-oligosaccharides, XOS, and monomers as glucose, and xylose. Naturally, $S$. cerevisiae can consume some mono- and disaccharides, such as D-glucose, D-galactose, D-fructose, 
D-mannose, maltose, sucrose, and trehalose (Lagunas 1993), which do not represent the totality of the sugar derived from lignocellulosic hydrolysate. It is well known in the scientific literature that economically feasible bioethanol production might include the use of all sugars available in the lignocellulosic biomass. Thereby, despite the poor fermentation performance of XOS-utilizing S. cerevisiae strains as compared to glucose/sucrose fermentations, the simultaneous co-fermentation of lignocellulosic-derived sugars may result in higher ethanol titers and will maximize the use of the carbon sources available in lignocellulosic feedstock.

\section{AUTHOR CONTRIBUTIONS}

This review arose out of the $\mathrm{PhD}$ work of DPP, supervised by $\mathrm{TOB}$, in which she spent time working in the laboratories of DJL

\section{REFERENCES}

Almeida, J. R., Modig, T., Petersson, A., Hähn-Hägerdal, B., Lidén, G., and GorwaGrauslund, M. F. (2007). Increased Tolerance and Conversion of Inhibitors in Lignocellulosic Hydrolysates by Saccharomyces Cerevisiae. J. Chem. Technol. Biotechnol. 82, 340-349. doi:10.1002/jctb.1676

Amorim, H. V., Lopes, M. L., de Castro Oliveira, J. V., Buckeridge, M. S., and Goldman, G. H. (2011). Scientific Challenges of Bioethanol Production in Brazil. Appl. Microbiol. Biotechnol. 91, 1267-1275. doi:10.1007/s00253-0113437-6

Banerjee, G., Car, S., Scott-Craig, J. S., Borrusch, M. S., and Walton, J. D. (2010). Rapid Optimization of Enzyme Mixtures for Deconstruction of Diverse Pretreatment/biomass Feedstock Combinations. Biotechnol. Biofuels 3, 1. doi:10.1186/1754-6834-3-22

Beg, Q. K., Kapoor, M., Mahajan, L., and Hoondal, G. S. (2001). Microbial Xylanases and Their Industrial Applications: A Review. Appl. Microbiol. Biotechnol. 56, 326-338. doi:10.1007/s002530100704

Bhardwaj, N., Kumar, B., and Verma, P. (2019). A Detailed Overview of Xylanases: an Emerging Biomolecule for Current and Future Prospective. Bioresour. Bioproc. 6, 1-40. doi:10.1186/s40643-019-0276-2

Biely, P. (1985). Microbial Xylanolytic Systems. Trends Biotechnol. 3, 286-290. doi:10.1016/0167-7799(85)90004-6

Biely, P., and Petráková, E. (1984). Novel Inducers of the Xylan-Degrading Enzyme System of Cryptococcus Albidus. J. Bacteriol. 160, 408-412. doi:10.1128/jb.160.1.408-412.1984

Biely, P., Singh, S., and Puchart, V. (2016). Towards Enzymatic Breakdown of Complex Plant Xylan Structures: State of the Art. Biotechnol. Adv. 34, 1260-1274. doi:10.1016/j.biotechadv.2016.09.001

Borgström, C., Wasserstrom, L., Almqvist, H., Broberg, K., Klein, B., Noack, S., et al. (2019). Identification of Modifications Procuring Growth on Xylose in Recombinant Saccharomyces cerevisiae Strains Carrying the Weimberg Pathway. Metab. Eng. 55, 1-11. doi:10.1016/j.ymben.2019.05.010

Bracher, J. M., Martinez-Rodriguez, O. A., Dekker, W. J. C., Verhoeven, M. D., Van Maris, A. J. A., and Pronk, J. T. (2019). Reassessment of Requirements for Anaerobic Xylose Fermentation by Engineered, Non-evolved Saccharomyces cerevisiae Strains. FEMS Yeast Res. 19, 1-15. doi:10.1093/femsyr/foy104

Brenelli, L. B., Figueiredo, F. L., Damasio, A., Franco, T. T., and Rabelo, S. C. (2020). An Integrated Approach to Obtain Xylo-Oligosaccharides from Sugarcane Straw: From Lab to Pilot Scale. Bioresour. Tech. 313, 123637. doi:10.1016/J. BIORTECH.2020.123637

Cabrini, K. T., and Gallo, C. R. (1999). Identificação De Leveduras No Processo De Fermentação Alcoólica Em Usina Do Estado De São Paulo, Brasil. Sci. Agric. (Piracicaba, Braz. 56, 207-216. doi:10.1590/S0103-90161999000100028

Chakdar, H., Kumar, M., Pandiyan, K., Singh, A., Nanjappan, K., Kashyap, P. L., et al. (2016). Bacterial Xylanases: Biology to Biotechnology. 3 Biotech. 6, 1-15. doi:10.1007/s13205-016-0457-z and Y-SJ. DPP wrote the initial draft under guidance of TOB. EK, RG, ARLD, TTF, DJL, Y-SJ and TOB revised the manuscript.

\section{FUNDING}

This research was conducted through funding from the São Paulo Research Foundation (FAPESP), grants \# 2015/50612-8, \#2018/ 17172-2, \#2018/01759-4, and \#2019/18075-3. EK and DJL acknowledge funding from BBSRC (BB/P017460/1). Grant \# 2015/50612-8 is a joint project with BB/P017460/1.

\section{ACKNOWLEDGMENTS}

We would like to thank funding provided by FAPESP and BBSRC.

Chandra Raj, K., and Chandra, T. S. (1995). A Cellulase-free Xylanase from AlkalitolerantAspergillus Fischeri Fxn1. Biotechnol. Lett. 17, 309-314. doi:10.1007/ BF01190644

Chávez, R., Schachter, K., Navarro, C., Peirano, A., Aguirre, C., Bull, P., et al. (2002). Differences in Expression of Two Endoxylanase Genes (xynA and xynB) from Penicillium purpurogenum. Gene 293, 161-168. doi:10.1016/S0378-1119(02)00720-5

Chen, C.-H., Yao, J.-Y., Yang, B., Lee, H.-L., Yuan, S.-F., Hsieh, H.-Y., et al. (2019b). Engineer Multi-Functional Cellulase/xylanase/ $\beta$-Glucosidase with Improved Efficacy to Degrade rice Straw. Bioresour. Tech. Rep. 5, 170-177. doi:10. 1016/j.biteb.2019.01.008

Chen, P., You, Q., Li, X., Chang, Q., Zhang, Y., Zheng, B., et al. (2019a). Polysaccharide Fractions from Fortunella Margarita Affect Proliferation of Bifidobacterium Adolescentis ATCC 15703 and Undergo Structural Changes Following Fermentation. Int. J. Biol. Macromolecules 123, 1070-1078. doi:10. 1016/J.IJBIOMAC.2018.11.163

Christakopoulos, P., Mamma, D., Nerinckx, W., Kekos, D., Macris, B., and Claeyssens, M. (1996a). Production and Partial Characterization of Xylanase from Fusarium Oxysporum. Bioresour. Tech. 58, 115-119. doi:10.1016/S09608524(96)00091-0

Christakopoulos, P., Nerinckx, W., Kekos, D., Macris, B., and Claeyssens, M. (1996b). Purification and Characterization of Two Low Molecular Mass Alkaline Xylanases from Fusarium Oxysporum F3. J. Biotechnol. 51, 181-189. doi:10.1016/0168-1656(96)01619-7

Cola, P., Procópio, D. P., Alves, A. T. d. C., Carnevalli, L. R., Sampaio, I. V., da Costa, B. L. V., et al. (2020). Differential Effects of Major Inhibitory Compounds from Sugarcane-Based Lignocellulosic Hydrolysates on the Physiology of Yeast Strains and Lactic Acid Bacteria. Biotechnol. Lett. 42, 571-582. doi:10.1007/ s10529-020-02803-6

Collins, T., Gerday, C., and Feller, G. (2005). Xylanases, Xylanase Families and Extremophilic Xylanases. FEMS Microbiol. Rev. 29, 3-23. doi:10.1016/j.femsre. 2004.06.005

Collins, T., Hoyoux, A., Dutron, A., Georis, J., Genot, B., Dauvrin, T., et al. (2006). Use of Glycoside Hydrolase Family 8 Xylanases in Baking. J. Cereal Sci. 43, 79-84. doi:10.1016/j.jcs.2005.08.002

Crous, J. M., Pretorius, I. S., and Van Zyl, W. H. (1995). Cloning and Expression of an Aspergillus Kawachii Endo-1,4- $\beta$-Xylanase Gene in Saccharomyces cerevisiae. Curr. Genet. 28, 467-473. doi:10.1007/BF00310817

Crous, J. M., Pretorius, I. S., and Van Zyl, W. H. (1996). Cloning and Expression of the $a$ - L -arabinofuranosidase Gene ( $\mathrm{ABF} 2$ ) of Aspergillus niger in Saccharomyces cerevisiae. Appl. Microbiol. Biotechnol. 46, 256-260. doi:10. $1007 / \mathrm{s} 002530050813$

Dahlman, O., Jacobs, A., and Sjöberg, J. (2003). Molecular Properties of Hemicelluloses Located in the Surface and Inner Layers of Hardwood and Softwood Pulps. Cellulose 10, 325-334. Available at: https://link.springer.com/ content/pdf/10.1023/A:1027316926308.pdf (Accessed September 7, 2020). doi:10.1023/a:1027316926308 
de Almeida, M. A., and Colombo, R. (2021). Production Chain of First-Generation Sugarcane Bioethanol: Characterization and Value-Added Application of Wastes. Bioenerg. Res. 1-16. doi:10.1007/s12155-021-10301-4

de Vries, R. P., Riley, R., Wiebenga, A., Aguilar-Osorio, G., Amillis, S., Uchima, C. A., et al. (20172017). Comparative Genomics Reveals High Biological Diversity and Specific Adaptations in the Industrially and Medically Important Fungal Genus Aspergillus. Genome Biol. 18, 28-45. doi:10.1186/S13059-017-1151-0

Della-Bianca, B. E., de Hulster, E., Pronk, J. T., van Maris, A. J. A., and Gombert, A. K. (2014). Physiology of the Fuel Ethanol strain Saccharomyces cerevisiae PE-2 at Low pH Indicates a Context-dependent Performance Relevant for Industrial Applications. FEMS Yeast Res. 14, 1196-1205. doi:10.1111/1567-1364.12217

Della-Bianca, B. E., and Gombert, A. K. (2013). Stress Tolerance and Growth Physiology of Yeast Strains from the Brazilian Fuel Ethanol Industry. Antonie van Leeuwenhoek 104, 1083-1095. doi:10.1007/s10482-013-0030-2

Delmas, S., Pullan, S. T., Gaddipati, S., Kokolski, M., Malla, S., Blythe, M. J., et al. (2012). Uncovering the Genome-wide Transcriptional Responses of the Filamentous Fungus Aspergillus niger to Lignocellulose Using RNA Sequencing. PLoS Genet. 8, e1002875-13. doi:10.1371/JOURNAL.PGEN. 1002875

Donald, K. A. G., Carle, A., Gibbs, M. D., and Bergquist, P. L. (1994). Production of a Bacterial Thermophilic Xylanase in Saccharomyces Cerevisiae. Appl. Microbiol. Biotechnol. 42, 309-312. doi:10.1007/BF00902734

dos Reis, T. F., de Lima, P. B. A., Parachin, N. S., Mingossi, F. B., de Castro Oliveira, J. V., Ries, L. N. A., et al. (2016). Identification and Characterization of Putative Xylose and Cellobiose Transporters in Aspergillus nidulans. Biotechnol. Biofuels 9, 204. doi:10.1186/s13068-016-0611-1

Dos Santos, L. V., Carazzolle, M. F., Nagamatsu, S. T., Sampaio, N. M. V., Almeida, L. D., Pirolla, R. A. S., et al. (2016). Unraveling the Genetic Basis of Xylose Consumption in Engineered Saccharomyces cerevisiae Strains. Sci. Rep. 6, 38676. doi:10.1038/srep38676

Eliasson, A., Christensson, C., Wahlbom, C. F., and Hahn-Hägerdal, B. (2000). Anaerobic Xylose Fermentation by Recombinant Saccharomyces cerevisiae Carrying XYL1 , XYL2, and XKS1 in Mineral Medium Chemostat Cultures. Appl. Environ. Microbiol. 66, 3381-3386. doi:10.1128/AEM.66.8. 3381-3386.2000

Fang, C., Wang, Q., Selvaraj, J. N., Zhou, Y., Ma, L., Zhang, G., et al. (2017). High Copy and Stable Expression of the Xylanase XynHB in Saccharomyces cerevisiae by rDNA-Mediated Integration. Sci. Rep. 7, 1-9. doi:10.1038/s41598-01708647-x

Fernandes Pereira, P. H., Cornelis, H., Voorwald, J., Odila, M., Cioff, H., Mulinari, D. R., et al. (2011). Sugarcane Bagasse Pulping and Bleaching: Thermal and Chemical Characterization. BioResources 6, 2471-2482. Available at: https://bioresources.cnr. ncsu.edu/wp-content/uploads/2016/06/BioRes_06_3_2471_FernandesP_VCMDP_ SCB_Pulp_Bleach_Therm_Chem_Char_987.pdf doi:10.15376/biores.6.1.867-878

Frommer, W. B., and Ninnemann, O. (1995). Heterologous Expression of Genes in Bacterial, Fungal, Animal, and Plant Cells. Annu. Rev. Plant Physiol. Plant Mol. Biol. 46, 419-444. doi:10.1111/1751-7915.12872

Fujii, T., Yu, G., Matsushika, A., Kurita, A., Yano, S., Murakami, K., et al. (2011). Ethanol Production from Xylo-Oligosaccharides by Xylose-Fermenting Saccharomyces cerevisiae Expressing $\beta$-Xylosidase. Biosci. Biotechnol. Biochem. 75, 1140-1146. doi:10.1271/bbb.110043

Fujita, Y., Katahira, S., Ueda, M., Tanaka, A., Okada, H., Morikawa, Y., et al. (2002). Construction of Whole-Cell Biocatalyst for Xylan Degradation through CellSurface Xylanase Display in Saccharomyces cerevisiae. J. Mol. Catal. B: Enzymatic 17, 189-195. doi:10.1016/S1381-1177(02)00027-9

Galbe, M., and Zacchi, G. (2002). A Review of the Production of Ethanol from Softwood. Appl. Microbiol. Biotechnol. 59, 618-628. doi:10.1007/s00253-0021058-9

Gárdonyi, M., and Hahn-Hägerdal, B. (2003). The Streptomyces Rubiginosus Xylose Isomerase Is Misfolded when Expressed in Saccharomyces cerevisiae. Enzyme Microb. Technol. 32, 252-259. doi:10.1016/S0141-0229(02)00285-5

Gírio, F. M., Fonseca, C., Carvalheiro, F., Duarte, L. C., Marques, S., and BogelŁukasik, R. (2010). Hemicelluloses for Fuel Ethanol: A Review. Bioresour. Tech. 101, 4775-4800. doi:10.1016/j.biortech.2010.01.088

Görgens, J. F., van Zyl, W. H., Knoetze, J. H., and Hahn-Hägerdal, B. (2001). The Metabolic burden of thePGK1andADH2promoter Systems for Heterologous Xylanase Production by Saccharomyces Cerevisiae in Defined Medium. Biotechnol. Bioeng. 73, 238-245. doi:10.1002/bit.1056
Grange, D. C. L., Pretorius, I. S., and Van Zyl, W. H. (1997). Cloning of the Bacillus Pumilus $\beta$-xylosidase Gene ( $\mathrm{xynB}$ ) and its Expression in Saccharomyces cerevisiae. Appl. Microbiol. Biotechnol. 47, 262-266. doi:10.1007/ s002530050924

Gueguen, Y., Chemardin, P., Labrot, P., Arnaud, A., and Galzy, P. (1997). Purification and Characterization of an Intracellular $\beta$-glucosidase from a New Strain of Leuconostoc Mesenteroides Isolated from Cassava. J. Appl. Microbiol. 82, 469-476. doi:10.1046/j.1365-2672.1997.00136.x

Gupta, A., and Verma, J. P. (2015). Sustainable Bio-Ethanol Production from AgroResidues: A Review. Renew. Sust. Energ. Rev. 41, 550-567. doi:10.1016/J.RSER. 2014.08.032

Harner, N. K., Wen, X., Bajwa, P. K., Austin, G. D., Ho, C.-Y., Habash, M. B., et al. (2015). Genetic Improvement of Native Xylose-Fermenting Yeasts for Ethanol Production. J. Ind. Microbiol. Biotechnol. 42, 1-20. doi:10.1007/s10295-014$1535-\mathrm{Z}$

Honda, Y., and Kitaoka, M. (2004). A Family 8 Glycoside Hydrolase from Bacillus Halodurans C-125 (BH2105) Is a Reducing End Xylose-Releasing ExoOligoxylanase. J. Biol. Chem. 279, 55097-55103. doi:10.1074/jbc.M409832200

Hou, J., Tyo, K. E. J., Liu, Z., Petranovic, D., and Nielsen, J. (2012). Metabolic Engineering of Recombinant Protein Secretion by Saccharomyces cerevisiae. FEMS Yeast Res. 12, 491-510. doi:10.1111/J.1567-1364.2012.00810.X

Jacobsen, S. E., and Wyman, C. E. (2000). Cellulose and Hemicellulose Hydrolysis Models for Application to Current and Novel Pretreatment Processes. Appl. Biochem. Biotechnol. 84, 81-96. doi:10.1385/ABAB:84-86:1-9:81

Jeffries, T. W. (1983). "Utilization of Xylose by Bacteria, Yeasts, and Fungi," in Pentoses and Lignin (Berlin/Heidelberg: Springer-Verlag), 1-32. doi:10.1007/ BFb0009101

Johnsen, U., Dambeck, M., Zaiss, H., Fuhrer, T., Soppa, J., Sauer, U., et al. (2009). D-xylose Degradation Pathway in the Halophilic Archaeon Haloferax Volcanii. J. Biol. Chem. 284, 27290-27303. doi:10.1074/jbc.M109.003814

Jørgensen, H., Kristensen, J. B., and Felby, C. (2007). Enzymatic Conversion of Lignocellulose into Fermentable Sugars: Challenges and Opportunities. Biofuels, Bioprod. Bioref. 1, 119-134. doi:10.1002/bbb.4

Katahira, S., Fujita, Y., Mizuike, A., Fukuda, H., and Kondo, A. (2004). Construction of a Xylan-Fermenting Yeast Strain through Codisplay of Xylanolytic Enzymes on the Surface of Xylose-Utilizing Saccharomyces cerevisiae Cells. Appl. Environ. Microbiol. 70, 5407-5414. doi:10.1128/AEM. 70.9.5407-5414.2004

Kim, J.-H., Kim, B.-W., Yoon, K.-H., and Nam, S.-W. (2000). Expression of Bacillus Sp. $\beta$-xylosidase Gene (xylB) in Saccharomyces cerevisiae. Biotechnol. Lett. 22, 1025-1029. doi:10.1023/a:1005661909095

Kim, M.-J., Kim, B.-H., Nam, S.-W., Choi, E.-S., Shin, D.-H., Cho, H.-Y., et al. (2013a). Efficient Secretory Expression of Recombinant Endoxylanase from Bacillus Sp. HY-20 in Saccharomyces cerevisiae. J. Life Sci. 23, 863-868. doi:10. 5352/jls.2013.23.7.863

Kim, S. R., Ha, S.-J., Wei, N., Oh, E. J., and Jin, Y.-S. (2012). Simultaneous Cofermentation of Mixed Sugars: A Promising Strategy for Producing Cellulosic Ethanol. Trends Biotechnol. 30, 274-282. doi:10.1016/j.tibtech.2012.01.005

Kim, S. R., Skerker, J. M., Kang, W., Lesmana, A., Wei, N., Arkin, A. P., et al. (2013b). Rational and Evolutionary Engineering Approaches Uncover a Small Set of Genetic Changes Efficient for Rapid Xylose Fermentation in Saccharomyces cerevisiae. PLoS One 8, e57048-13. doi:10.1371/journal.pone. 0057048

Kulkarni, N., Shendye, A., and Rao, M. (1999). Molecular and Biotechnological Aspects of Xylanases. FEMS Microbiol. Rev. 23, 411-456. doi:10.1111/j.15746976.1999.tb00407.x

Kuyper, M., Hartog, M., Toirkens, M., Almering, M., Winkler, A., Vandijken, J., et al. (2005). Metabolic Engineering of a Xylose-Isomerase-Expressing Strain for Rapid Anaerobic Xylose Fermentation. FEMS Yeast Res. 5, 399-409. doi:10. 1016/j.femsyr.2004.09.010

Kwak, S., and Jin, Y.-S. (2017). Production of Fuels and Chemicals from Xylose by Engineered Saccharomyces cerevisiae: A Review and Perspective. Microb. Cel. Fact. 16, 1-15. doi:10.1186/s12934-017-0694-9

La Grange, D. C., Claeyssens, M., Pretorius, I. S., and Van Zyl, W. H. (2000). Coexpression of the Bacillus Pumilus $\beta$-xylosidase ( $x y n B$ ) Gene with the Trichoderma Reesei $\beta$-xylanase 2 ( Xyn2 ) Gene in the Yeast Saccharomyces cerevisiae. Appl. Microbiol. Biotechnol. 54, 195-200. doi:10.1007/ s002530000372 
La Grange, D. C., Pretorius, I. S., Claeyssens, M., and Van Zyl, W. H. (2001). Degradation of Xylan to D -Xylose by Recombinant Saccharomyces cerevisiae Coexpressing the Aspergillus niger $\beta$-Xylosidase $(x \ln D$ ) and the Trichoderma Reesei Xylanase II ( Xyn2 ) Genes. Appl. Environ. Microbiol. 67, 5512-5519. doi:10.1128/AEM.67.12.5512-5519.2001

La Grange, D. C., Pretorius, I. S., and Van Zyl, W. H. (1996). Expression of a Trichoderma Reesei Beta-Xylanase Gene (XYN2) in Saccharomyces cerevisiae. Appl. Environ. Microbiol. 62, 1036-1044. doi:10.1128/aem.62.3.1036-1044.1996

Lagunas, R. (1993). Sugar Transport in Saccharomyces Cerevisiae. FEMS Microbiol. Rev. 104, 229-242. doi:10.1111/J.1574-6968.1993.TB05869.X

Lee, J. H., Lim, M. Y., Kim, M. J., Heo, S. Y., Seo, J. H., Kim, Y. H., et al. (2007). Constitutive Coexpression of Bacillus Endoxylanase and Trichoderma Endoglucanase Genes in Saccharomyces cerevisiae. J. Microbiol. Biotechnol. 17, 2076-2080. Available at: http://www.jmb.or.kr/submission/Journal/017/ JMB017-12-24.pdf.

Lee, J. H., Heo, S.-Y., Lee, J.-W., Yoon, K.-H., Kim, Y.-H., and Nam, S.-W. (2009). Thermostability and Xylan-Hydrolyzing Property of Endoxylanase Expressed in Yeast Saccharomyces cerevisiae. Biotechnol. Bioproc. E 14, 639-644. doi:10. 1007/s12257-009-0014-2

Lee, S.-M., Jellison, T., and Alper, H. S. (2015). Xylan Catabolism Is Improved by Blending Bioprospecting and Metabolic Pathway Engineering in Saccharomyces Cerevisiae. Biotechnol. J. 10, 575. doi:10.1002/biot.201400622

Li, X., Chen, Y., and Nielsen, J. (2019). Harnessing Xylose Pathways for Biofuels Production. Curr. Opin. Biotechnol. 57, 56-65. doi:10.1016/j.copbio.2019. 01.006

Li, X. L., and Ljungdahl, L. G. (1996). Expression of Aureobasidium Pullulans xynA in, and Secretion of the Xylanase from, Saccharomyces cerevisiae. Appl. Environ. Microbiol. 62, 209-213. doi:10.1128/aem.62.1.209-213.1996

Li, X., Yu, V. Y., Lin, Y., Chomvong, K., Estrela, R., Park, A., et al. (2015). Expanding Xylose Metabolism in Yeast for Plant Cell wall Conversion to Biofuels. Elife 4. e05896, doi:10.7554/eLife.05896

Li, Z., Qu, H., Li, C., and Zhou, X. (2013). Direct and Efficient Xylitol Production from Xylan by Saccharomyces cerevisiae through Transcriptional Level and Fermentation Processing Optimizations. Bioresour. Tech. 149, 413-419. doi:10. 1016/j.biortech.2013.09.101

Liu, L., Cheng, J., Chen, H., Li, X., Wang, S., Song, A., et al. (2011). Directed Evolution of a Mesophilic Fungal Xylanase by Fusion of a Thermophilic Bacterial Carbohydrate-Binding Module. Process Biochem. 46, 395-398. doi:10.1016/j.procbio.2010.07.026

Liu, L., Qin, Y., Wang, Y., Li, H., Shang, N., and Li, P. (2014). Complete Genome Sequence of Bifidobacterium Animalis RH, a Probiotic Bacterium Producing Exopolysaccharides. J. Biotechnol. 189, 86-87. doi:10.1016/J.JBIOTEC.2014. 08.041

Lopes, D. D., Rosa, C. A., Hector, R. E., Dien, B. S., Mertens, J. A., Ayub, M. A. Z., et al. (2017). Influence of Genetic Background of Engineered XyloseFermenting Industrial Saccharomyces cerevisiae Strains for Ethanol Production from Lignocellulosic Hydrolysates. J. Ind. Microbiol. Biotechnol. 44, 1575-1588. doi:10.1007/s10295-017-1979-z

Lopes, T. S., de Wijs, I. J., Steenhauer, S. I., Verbakel, J., and Planta, R. J. (1996). Factors Affecting the Mitotic Stability of High-Copy-Number Integration into the Ribosomal DNA of Saccharomyces Cerevisiae. Yeast 12, 467-477. doi:10. 1002/(SICI)1097-0061

Luttig, M., Pretorius, I. S., and Zyl, W. H. v. (1997). Cloning of Two $\beta$-xylanaseencoding Genes from Aspergillus niger and Their Expression in Saccharomyces cerevisiae. Biotechnol. Lett. 19, 411-415. doi:10.1023/A:1018327623422

Lynd, L. R., Laser, M. S., Bransby, D., Dale, B. E., Davison, B., Hamilton, R., et al. (2008). How Biotech Can Transform Biofuels. Nat. Biotechnol. 26, 169-172. doi:10.1038/nbt0208-169

Lynd, L. R., Weimer, P. J., van Zyl, W. H., and Pretorius, I. S. (2002).Microbial Cellulose Utilization: Fundamentals and Biotechnology, Microbiol. Mol. Biol. Rev. 66, 506-577. doi:10.1128/MMBR.66.3.506-577.2002/ASSET/38C13E200334-4477-8327-F000A9C877DC/ASSETS/GRAPHIC/MR032001411T

Ma, J., and Ptashne, M. (1987). Deletion Analysis of GAL4 Defines Two Transcriptional Activating Segments. Cell 48, 847-853. doi:10.1016/00928674(87)90081-X

Margaritis, A., and Bajpai, P. (1982). Direct Fermentation of D -Xylose to Ethanol by Kluyveromyces Marxianus Strains. Appl. Environ. Microbiol. 44, 1039-1041. doi:10.1128/aem.44.5.1039-1041.1982
Margolles-Clark, E., Tenkanen, M., Nakari-Setälä, T., Penttilä, M., Seta"la", S., Penttila"*, M., et al. (1996). Cloning of Genes Encoding Alpha-LArabinofuranosidase and Beta-Xylosidase from Trichoderma Reesei by Expression in Saccharomyces cerevisiae. Appl. Environ. Microbiol. 62, 3840-3846. doi:10.1128/aem.62.10.3840-3846.1996

Mert, M. J., la Grange, D. C., Rose, S. H., and van Zyl, W. H. (2016). Engineering of Saccharomyces cerevisiae to Utilize Xylan as a Sole Carbohydrate Source by Co-expression of an Endoxylanase, Xylosidase and a Bacterial Xylose Isomerase. J. Ind. Microbiol. Biotechnol. 43, 431-440. doi:10.1007/s10295-015-1727-1

Mishra, C., Keskar, S., and Rao, M. (1984). Production and Properties of Extracellular Endoxylanase from Neurospora Crassa. Appl. Environ. Microbiol. 48, 224-228. doi:10.1128/aem.48.1.224-228.1984

Mittelman, K., and Barkai, N. (2017). The Genetic Requirements for Pentose Fermentation in Budding Yeast. G3 Genes, Genomes, Genet. 7, 1743-1752. doi:10.1534/g3.117.039610

Moreau, A., Durand, S., and Morosoli, R. (1992). Secretion of a Cryptococcus Albidus Xylanase in Saccharomyces cerevisiae. Gene 116, 109-113. doi:10.1016/ 0378-1119(92)90637-5

Moreira, L. R. S., and Filho, E. X. F. (2016). Insights into the Mechanism of Enzymatic Hydrolysis of Xylan. Appl. Microbiol. Biotechnol. 100, 5205-5214. doi:10.1007/s00253-016-7555-z

Najjarzadeh, N., Matsakas, L., Rova, U., and Christakopoulos, P. (2020). Effect of Oligosaccharide Degree of Polymerization on the Induction of XylanDegrading Enzymes by Fusarium Oxysporum F. Sp. Lycopersici. Molecules 25, 5849. doi:10.3390/molecules 25245849

Nevoigt, E. (2008). Progress in Metabolic Engineering of Saccharomyces cerevisiae. Microbiol. Mol. Biol. Rev. 72, 379-412. doi:10.1128/MMBR.00025-07

Nielsen, J. (2019). Yeast Systems Biology: Model Organism and Cell Factory. Biotechnol. J. 14, 1800421. doi:10.1002/biot.201800421

Nieves, R. A., Ehrman, C. I., Adney, W. S., Elander, R. T., and Himmel, M. E. (1997). Survey and Analysis of Commercial Cellulase Preparations Suitable for Biomass Conversion to Ethanol. World J. Microbiol. Biotechnol. 14, 301-304. doi:10.1023/A:1008871205580

Niu, Y., Wu, L., Shen, Y., Zhao, J., Zhang, J., Yi, Y., et al. (2019). Coexpression of $\beta$ xylosidase and Xylose Isomerase in Saccharomyces cerevisiae Improves the Efficiency of Saccharification and Fermentation from Xylo-Oligosaccharides. Cellulose 26, 7923-7937. doi:10.1007/s10570-019-02650-3

Nuyens, F., Van Zyl, W. H., Iserentant, D., Verachtert, H., and Michiels, C. (2001). Heterologous Expression of the Bacillus Pumilus Endo- $\beta$-Xylanase ( xynA ) Gene in the Yeast Saccharomyces cerevisiae. Appl. Microbiol. Biotechnol. 56, 431-434. doi:10.1007/s002530100670

Oh, E. J., and Jin, Y.-S. (2020). Engineering of Saccharomyces cerevisiae for Efficient Fermentation of Cellulose. FEMS Yeast Res. 20. doi:10.1093/femsyr/foz089

Palmqvist, E., and Hahn-Hägerdal, B. (2000a). Fermentation of Lignocellulosic Hydrolysates. I: Inhibition and Detoxification. Bioresour. Technol. 187, 228-234. doi:10.1016/j.biortech.2015.03.129

Palmqvist, E., and Hahn-Hägerdal, B. (2000b). Fermentation of Lignocellulosic Hydrolysates. II: Inhibitors and Mechanisms of Inhibition. Bioresour. Tech. 74, 25-33. doi:10.1016/S0960-8524(99)00161-3

Pan, C.-X., Xu, W.-Z., Akatsuka, H., Negoro, S., Shima, Y., Urabe, I., et al. (1991). Expression of the Xylan-Degrading Genes of Bacillus Pumilus IPO in Saccharomyces cerevisiae. J. Ferment. Bioeng. 71, 303-308. doi:10.1016/0922$338 \mathrm{X}(91) 90340-\mathrm{M}$

Panbangred, W., Shinmyo, A., Kinoshita, S., and Okada, H. (1983). Purification and Properties of Endoxylanase Produced by bacillus Pumilus. Agric. Biol. Chem. 47, 957-963. doi:10.1080/00021369.1983.1086576010.1271/bbb1961. 47.957

Parachin, N. S., Siqueira, S., de Faria, F. P., Torres, F. A. G., and de Moraes, L. M. P. (2009). Xylanases from Cryptococcus Flavus Isolate I-11: Enzymatic Profile, Isolation and Heterologous Expression of CfXYN1 in Saccharomyces cerevisiae. J. Mol. Catal. B: Enzymatic 59, 52-57. doi:10.1016/j.molcatb.2008.12.018

Patiño, M. A., Ortiz, J. P., Velásquez, M., and Stambuk, B. U. (2019). D-Xylose Consumption by nonrecombinant Saccharomyces Cerevisiae: A Review. Yeast 36, 3429. doi: $10.1002 /$ yea. 3429

Pedersen, M., and Meyer, A. S. (2010). Lignocellulose Pretreatment Severity Relating pH to Biomatrix Opening. New Biotechnol. 27, 739-750. doi:10.1016/J. NBT.2010.05.003 
Peng, S., Cao, Q., Qin, Y., Li, X., Liu, G., and Qu, Y. (2017). An Aldonolactonase AltA from Penicillium oxalicum Mitigates the Inhibition of $\beta$-glucosidase during Lignocellulose Biodegradation. Appl. Microbiol. Biotechnol. 101, 3627-3636. doi:10.1007/s00253-017-8134-7

Pérez-Gonzalez, J. A., De Graaff, L. H., Visser, J., and Ramón, D. (1996). Molecular Cloning and Expression in Saccharomyces cerevisiae of Two Aspergillus nidulans Xylanase Genes. Appl. Environ. Microbiol. 62, 2179-2182. doi:10. 1128/aem.62.6.2179-2182.1996

Petrescu, I., Lamotte-Brasseur, J., Chessa, J.-P., Ntarima, P., Claeyssens, M., Devreese, B., et al. (2000). Xylanase from the Psychrophilic Yeast Cryptococcus Adeliae. Extremophiles 4, 137-144. doi:10.1007/s007920070028

Polizeli, M. L. T. M., Rizzatti, A. C. S., Monti, R., Terenzi, H. F., Jorge, J. A., and Amorim, D. S. (2005). Xylanases from Fungi: Properties and Industrial Applications. Appl. Microbiol. Biotechnol. 67, 577-591. doi:10.1007/s00253005-1904-7

Qian, Y., Yomano, L. P., Preston, J. F., Aldrich, H. C., and Ingram, L. O. (2003). Cloning, Characterization, and Functional Expression of the Klebsiella Oxytoca Xylodextrin Utilization Operon ( xynTB ) in Escherichia coli. Appl. Environ. Microbiol. 69, 5957-5967. doi:10.1128/AEM.69.10.5957-5967.2003

Rennie, E. A., and Scheller, H. V. (2014). Xylan Biosynthesis. Curr. Opin. Biotechnol. 26, 100-107. doi:10.1016/j.copbio.2013.11.013

Royer, J. C., and Nakas, J. P. (1989). Xylanase Production by Trichoderma Longibrachiatum. Enzyme Microb. Tech. 11, 405-410. doi:10.1016/01410229(89)90134-8

Ryabova, O., Chmil, O., and Sibirny, A. (2003). Xylose and Cellobiose Fermentation to Ethanol by the Thermotolerant Methylotrophic Yeast. FEMS Yeast Res. 4, 157-164. doi:10.1016/S1567-1356(03)00146-6

Saito, Y., Shigehisa, A., Watanabe, Y., Tsukuda, N., Moriyama-Ohara, K., Hara, T., et al. (2020). Multiple Transporters and Glycoside Hydrolases Are Involved in Arabinoxylan-Derived Oligosaccharide Utilization in Bifidobacterium Pseudocatenulatum. Appl. Environ. Microbiol. 86. doi:10.1128/AEM.0178220/SUPPL_FILE/AEM.01782-20-S0001

Saitoh, S., Tanaka, T., and Kondo, A. (2011). Co-fermentation of Cellulose/xylan Using Engineered Industrial Yeast Strain OC-2 Displaying Both $\beta$-glucosidase and $\beta$-xylosidase. Appl. Microbiol. Biotechnol. 91, 1553-1559. doi:10.1007/ s00253-011-3357-5

Sakamoto, T., Hasunuma, T., Hori, Y., Yamada, R., and Kondo, A. (2012). Direct Ethanol Production from Hemicellulosic Materials of rice Straw by Use of an Engineered Yeast Strain Codisplaying Three Types of Hemicellulolytic Enzymes on the Surface of Xylose-Utilizing Saccharomyces cerevisiae Cells. J. Biotechnol. 158, 203-210. doi:10.1016/j.jbiotec.2011.06.025

Sarthy, A. V., McConaughy, B. L., Lobo, Z., Sundstrom, J. A., Furlong, C. E., and Hall, B. D. (19872000). Expression of the Escherichia coli Xylose Isomerase Gene in Saccharomyces cerevisiae. Appl. Environ. Microbiol. 53, 1996-2000. doi:10.1128/aem.53.9.1996-2000.1987

Schuster, A., and Schmoll, M. (2010). Biology and Biotechnology of Trichoderma. Appl. Microbiol. Biotechnol. 87, 787-799. doi:10.1007/s00253-010-2632-1

Sekar, R., Shin, H. D., and DiChristina, T. J. (2016). Direct Conversion of Cellulose and Hemicellulose to Fermentable Sugars by a Microbially-Driven Fenton Reaction. Bioresour. Tech. 218, 1133-1139. doi:10.1016/j.biortech.2016.07.087

Shen, L., Kohlhaas, M., Enoki, J., Meier, R., Schönenberger, B., Wohlgemuth, R., et al. (2020). A Combined Experimental and Modelling Approach for the Weimberg Pathway Optimisation. Nat. Commun. 11, 1-13. doi:10.1038/ s41467-020-14830-y

Shulami, S., Zaide, G., Zolotnitsky, G., Langut, Y., Feld, G., Sonenshein, A. L., et al. (2007). A Two-Component System Regulates the Expression of an ABC Transporter for Xylo-Oligosaccharides in Geobacillus Stearothermophilus. Appl. Environ. Microbiol. 73, 874-884. doi:10.1128/AEM.02367-06

Smiley, K. L., and Bolen, P. L. (1982). Demonstration of D-Xylose Reductase and D-Xylitol Dehydrogenase in Pachysolen Tannophilus. Biotechnol. Lett. 4, 607-610. doi:10.1007/BF00127793

Stephens, C., Christen, B., Fuchs, T., Sundaram, V., Watanabe, K., and Jenal, U. (2007). Genetic Analysis of a Novel Pathway for D -Xylose Metabolism in Caulobacter crescentus. J. Bacteriol. 189, 2181-2185. doi:10.1128/JB.01438-06

Stincone, A., Prigione, A., Cramer, T., Wamelink, M. M. C., Campbell, K., Cheung, E., et al. (2015). The Return of Metabolism: Biochemistry and Physiology of the Pentose Phosphate Pathway. Biol. Rev. 90, 927-963. doi: $10.1111 /$ brv. 12140
Subramaniyan, S., and Prema, P. (2002). Biotechnology of Microbial Xylanases: Enzymology, Molecular Biology, and Application. Crit. Rev. Biotechnol. 22, 33-64. doi:10.1080/07388550290789450

Sun, J., Wen, F., Si, T., Xu, J.-H., and Zhao, H. (2012). Direct Conversion of Xylan to Ethanol by Recombinant Saccharomyces cerevisiae Strains Displaying an Engineered Minihemicellulosome. Appl. Environ. Microbiol. 78, 3837-3845. doi:10.1128/AEM.07679-11

Sun, Y., and Cheng, J. (2002). Hydrolysis of Lignocellulosic Materials for Ethanol Production: A Review. Bioresour. Tech. 83, 1-11. doi:10.1016/S0960-8524(01) $00212-7$

Sunna, A., and Antranikian, G. (1997). Xylanolytic Enzymes from Fungi and Bacteria. Crit. Rev. Biotechnol. 17, 39-67. doi:10.3109/07388559709146606

Tabañag, I. D. F., Chu, I.-M., Wei, Y.-H., and Tsai, S.-L. (2018). Ethanol Production from Hemicellulose by a Consortium of Different Genetically-Modified Sacharomyces Cerevisiae. J. Taiwan Inst. Chem. Eng. 89, 15-25. doi:10.1016/ j.jtice.2018.04.029

Tafakori, V., Torktaz, I., Doostmohamadi, M., and Ahmadain, G. (2012). Microbial Cell Surface Display; its Medical and Environmental Applications. Iran. J. Biotechnol. 10, 231-239. Available at: https://www.researchgate.net/ publication/232708479_Microbial_cell_surface_display_its_medical_and_ environmental_applications (Accessed January 21, 2021).

Tengborg, C., Stenberg, K., Galbe, M., Zacchi, G., Larsson, S., Palmqvist, E., et al. (1998). Comparison of SO2 and H2SO4 Impregnation of Softwood Prior to Steam Pretreatment on Ethanol Production. Applied Biochemistry and Biotechnology 70-2, 3-15. doi:10.1007/BF02920119

Tian, B., Xu, Y., Cai, W., Huang, Q., Gao, Y., Li, X., et al. (2013). Molecular Cloning and Overexpression of an Endo- $\beta$-1,4-Xylanase Gene from Aspergillus niger in Industrial Saccharomyces cerevisiae YS2 Strain. Appl. Biochem. Biotechnol. 170, 320-328. doi:10.1007/s12010-013-0173-7

Toivola, A., Yarrow, D., Van Den Bosch, E., van Dijken, J. P., and Scheffers, W. A. (1984). Alcoholic Fermentation of D -Xylose by Yeasts. Appl. Environ. Microbiol. 47, 1221-1223. doi:10.1128/aem.47.6.1221-1223.1984

Tran Nguyen Hoang, P., Ko, J. K., Gong, G., Um, Y., and Lee, S.-M. (2018). Genomic and Phenotypic Characterization of a Refactored Xylose-Utilizing Saccharomyces cerevisiae Strain for Lignocellulosic Biofuel Production. Biotechnol. Biofuels 11, 268. doi:10.1186/s13068-018-1269-7

Van Petegem, F., Collins, T., Meuwis, M.-A., Gerday, C., Feller, G., and Van Beeumen, J. (2002). Crystallization and Preliminary X-ray Analysis of a Xylanase from the psychrophilePseudoalteromonas Haloplanktis. Acta Crystallogr. D Biol. Cryst. 58, 1494-1496. doi:10.1107/S0907444902011666

Velasco, J., Oliva, B., Mulinari, E. J., Quintero, L. P., da Silva Lima, A., Gonçalves, A. L., et al. (2019). Heterologous Expression and Functional Characterization of a GH10 Endoxylanase from Aspergillus fumigatus Var. Niveus with Potential Biotechnological Application. Biotechnol. Rep. 24, e00382. doi:10.1016/j.btre. 2019.e00382

Verduyn, C., Postma, E., Scheffers, W. A., and Van Dijken, J. P. (1992). Effect of Benzoic Acid on Metabolic Fluxes in Yeasts: a Continuous-Culture Study on the Regulation of Respiration and Alcoholic Fermentation. Yeast 8, 501-517. doi:10.1002/yea.320080703

Verhamme, T., Arents, J. C., Postma, P. W., Crielaard, W., and Hellingwerf, K. J. (2002). Investigation of In Vivo Cross-Talk between Key Two-Component Systems of Escherichia coli. Microbiology 148 (Pt 1), 69-78. doi:10.1099/ 00221287-148-1-69

Wang, C., Lu, X., Gao, J., Li, X., and Zhao, J. (2018). Xylo-oligosaccharides Inhibit Enzymatic Hydrolysis by Influencing Enzymatic Activity of Cellulase from Penicillium oxalicum. Energy Fuels 32, 9427-9437. doi:10.1021/acs.energyfuels. 8 b01424

Weimberg, R. (1961). Pentose Oxidation by Pseudomonas Fragi. J. Biol. Chem. 236, 629-635. doi:10.1016/s0021-9258(18)64279-6

Whistler, R. L., and Masak, E., Jr. (1955). Enzymatic Hydrolysis of Xylan1. J. Am. Chem. Soc. 77, 1241-1243. doi:10.1021/JA01610A042

Wierzbicki, M. P., Maloney, V., Mizrachi, E., and Myburg, A. A. (2019). Xylan in the Middle: Understanding Xylan Biosynthesis and its Metabolic Dependencies toward Improving wood Fiber for Industrial Processing. Front. Plant Sci. 10, 1-29. doi:10.3389/fpls.2019.00176

Wong, K. K., Tan, L. U., and Saddler, J. N. (1988). Multiplicity of Beta-1,4-Xylanase in Microorganisms: Functions and Applications. Microbiol. Rev. 52, 305-317. doi:10.1128/mmbr.52.3.305-317.198810.1128/mr.52.3.305-317.1988 
Woodward, J., and Wiseman, A. (1982). Fungal and Other $\beta$-d-glucosidases - Their Properties and Applications. Enzyme Microb. Tech. 4, 73-79. doi:10.1016/01410229(82)90084-9

Xia, P.-F., Zhang, G.-C., Liu, J.-J., Kwak, S., Tsai, C.-S., Kong, I. I., et al. (2016). GroE Chaperonins Assisted Functional Expression of Bacterial Enzymes in Saccharomyces Cerevisiae. Biotechnol. Bioeng. 113, 2149-2155. doi:10.1002/bit. 25980

Xiao, W., Li, H., Xia, W., Yang, Y., Hu, P., Zhou, S., et al. (2019). Co-expression of Cellulase and Xylanase Genes in Sacchromyces cerevisiae toward Enhanced Bioethanol Production from Corn stover. Bioengineered 10, 513-521. doi:10. 1080/21655979.2019.1682213

Yegin, S. (2017). Single-step Purification and Characterization of an Extreme Halophilic, Ethanol Tolerant and Acidophilic Xylanase from Aureobasidium Pullulans NRRL Y-2311-1 with Application Potential in the Food Industry. Food Chem. 221, 67-75. doi:10.1016/j.foodchem.2016.10.003

Zhang, C., Acosta-Sampson, L., Yu, V. Y., and Cate, J. H. D. (2017a). Screening of Transporters to Improve Xylodextrin Utilization in the Yeast Saccharomyces cerevisiae. PLoS One 12, e0184730. doi:10.1371/journal.pone.0184730

Zhang, G.-C., Turner, T. L., and Jin, Y.-S. (2017b). Enhanced Xylose Fermentation by Engineered Yeast Expressing NADH Oxidase through High Cell Density Inoculums. J. Ind. Microbiol. Biotechnol. 44, 387-395. doi:10.1007/s10295-016-1899-3

Zhang, G. M., Huang, J., Huang, G. R., Ma, L. X., and Zhang, X. E. (2007). Molecular Cloning and Heterologous Expression of a New Xylanase Gene from
Plectosphaerella Cucumerina. Appl. Microbiol. Biotechnol. 74, 339-346. doi:10. 1007/s00253-006-0648-3

Zhang, J., Tang, M., and Viikari, L. (2012). Xylans Inhibit Enzymatic Hydrolysis of Lignocellulosic Materials by Cellulases. Bioresour. Tech. 121, 8-12. doi:10.1016/ j.biortech.2012.07.010

Conflict of Interest: The authors declare that the research was conducted in the absence of any commercial or financial relationships that could be construed as a potential conflict of interest.

Publisher's Note: All claims expressed in this article are solely those of the authors and do not necessarily represent those of their affiliated organizations, or those of the publisher, the editors and the reviewers. Any product that may be evaluated in this article, or claim that may be made by its manufacturer, is not guaranteed or endorsed by the publisher.

Copyright (c) 2022 Procópio, Kendrick, Goldbeck, Damasio, Franco, Leak, Jin and Basso. This is an open-access article distributed under the terms of the Creative Commons Attribution License (CC BY). The use, distribution or reproduction in other forums is permitted, provided the original author(s) and the copyright owner(s) are credited and that the original publication in this journal is cited, in accordance with accepted academic practice. No use, distribution or reproduction is permitted which does not comply with these terms. 